\title{
Реконструкция дичных местоимений в убангийских языках
}

\begin{abstract}
Настоящая работа продолжает серию публикаций по сравнительному анализу личных местоимений и личных показателей в языках нигеро-конголезской макросемьи. В статье исследуются личные показатели языков убанги (Центральная Африка), проводится ступенчатая реконструкция праязыковой парадигмы местоимений.
\end{abstract}

Ключевые слова: личные местоимения, убангийские языки, нигеро-конголезские языки, языки Африки.

Семья языков убанги (или убангийских языков) объединяет около семидесяти языковых единиц (71, согласно данным каталога [Lewis 2009]); эта цифра весьма приблизительна, так как некоторые идиомы близки друг другу вплоть до взаимопонимаемости, и прежде их нередко рассматривали как диалекты одного языка. В последние десятилетия в связи с ростом детализации языковых описаний не меньше двух десятков идиомов получили признание в литературе в качестве полноправных языков: так, ещё в 1989 г. к группе нгбанди было принято относить только одноимённый язык [Boyd 1989: 193], сегодня в её составе насчитывают уже шесть языков [Lewis 2009: 687, 694-695].

Носители языков убанги населяют обширный ареал в самом сердце африканского континента. Большая часть этого ареала расположена в бассейне рек Мбому, Уэле и образованной их слиянием реки Убанги, чем и объясняется название языковой семьи, выдержанное вполне в лингвонимических традициях африканского языкознания. Общую численность носителей языков семьи можно приблизительно оценить в 3-4 млн. человек ([Williamson \& Blench 2000] дают цифру в 2.3 млн. по оценке 1978 г.). Языки убанги граничат на западе с языками адамауа, на севере и востоке - с нило-сахарскими языками (в основном принадлежащими к центральносуданской семье, на западе и юго-западе также к нилотской семье), на юге - с языками банту семьи бенуэ-конго.

В 1924 г. об убангийской группе из 25 языков впервые написал М. Делафосс [Delafosse 1924], включивший её в состав «негро-африканской» семьи языков, а в 1935 г. Й. Вильс включал их в т. н. «экваториальную» семью. В 1940 г. языки убанги были введены в состав большого генетического конгломерата «суданских языков» [Baumann, Thumwald \& Westermann 1940].

Одна из первых попыток внутренней классификации ряда убангийских языков была сделана в статье миссионера Р. Мортье, вышедшей в свет в небольшом журнале в Бельгийском Конго в разгар Второй мировой войны [Mortier 1941]. Её автор относил «небантуские» языки бассейна Убанги, которые он делил на пять групп, к «восточносуданским» языкам [Mortier 1946] - опять же пользуясь терминологией Д. Вестермана [Westermann 1911].

В своей работе [Greenberg 1963] Дж. Гринберг ввёл языки бассейнов рек Адамауа и Убанги в состав нигеро-конголезской макросемьи, объединив их под условным наименованием «адамауа-восточных» (Adamawa-Eastern), так как зона их распространения сильно выдавалась на восток от западноафриканского региона. Ранее языки этого обширного региона, в массе своей неизученные в должной степени, рассматривались как некласси- 
фицированные группы или «кластеры», как о них писали в середине XX столетия [Westermann \& Bryan 1952; Tucker \& Bryan 1956; Richardson 1957]. Позже данная семья языков получила название адамауа-убанги [Samarin 1971], принятое и сегодня.

В 1970-е и 1980-е годы появилось не менее трёх десятков описаний различных языков и диалектов семьи. Сравнительный анализ данных между собой, а также с языками адамауа проводился в основном методами статистического сопоставления списков лексики. При этом лексикостатистические расчёты показали значительные расхождения не только между группами языков адамауа и убанги, но и между идиомами в составе двух ветвей. В работах [Samarin 1971; Bennett 1983] было показано, что степень близости целого ряда языков и групп языков между собой настолько невысока, что говорить с уверенностью об адамауа-убангийской генетической общности по крайней мере преждевременно. Так, даже в географически смежных языках каре (адамауа) и бозом (убанги) Центральноафриканской Республики (ЦАР) сравнение базовой лексики показывает лишь 9-10\% возможных генетически родственных пар [Samarin 1971: 224-225]. Позже к лексикостатистическим материалам добавились данные сопоставления фонологии и морфологии, усилившие обоснованность той точки зрения, что языки адамауа и убанги следует рассматривать как две независимые семьи в рамках нигеро-конголезских языков.

В последние годы ряд исследователей предложили и другие гипотезы о внешней генетической классификации языков убанги. Так, Р. Бленч некоторое время отстаивал идею существования т. н. «саваннской семьи» языков Африки [Williamson \& Blench 2000], объединяющей языки гур, убанги, ряд языков адамауа и, возможно, изолированный язык пре. В 2008 г. Х. Диммендаль [Dimmendaal 2008] высказался за исключение семьи языков убанги из состава нигеро-конголезской макросемьи, т. к. она, по его мнению, «не подходит» под лексические и грамматические критерии родства, применимые к другим семьям языков нигер-конго.

Убангийские языки представляют собой довольно компактную картину для анализа в сравнении не только с гипотетическим адамауа-убангийским объединением, но и с соседней семьёй адамауа. Их классификация по Дж. Гринбергу, состоящая из восьми групп [Greenberg 1963: 9], была модифицирована в работе У. Самарина [Samarin 1971: 225 , со ссылкой на личное сообщение А. Букио и Ж. Тома] и сведена к пяти ветвям. Эта классификация впоследствии многократно пересматривалась и уточнялась, однако, как и прежде, основанием для пересмотра служили лишь несистемные сопоставления списков слов, пестревшие белыми пятнами и фонетическими ошибками, а также типология фонологических и морфологических систем. Так, например, группа языков банда постулировалась, исходя из особенностей фонологии и существования именных префиксов [Воуd 1989: 191]. В этой работе Р. Бойд предложил классификацию языков убанги, остающуюся общепринятой и по сей день. Эта классификация представлена на Диаграмме 1 и разделяет языки семьи на три ветви: гбая, банда-нгбанди-сере (в свою очередь, подразделяемую на три группы) и занде.

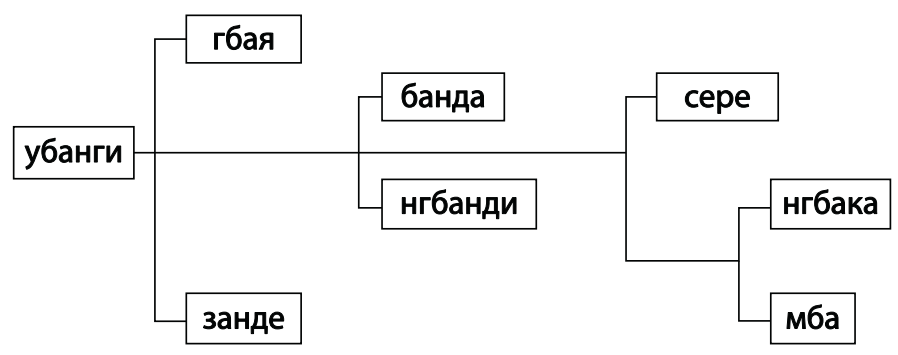

Диаграмиа 1 
Степень изученности языков трёх основных ветвей убангийских языков с точки зрения сравнительного анализа крайне неоднородна. Впечатляющих и надёжных результатов компаративистам удалось достичь, пожалуй, только в сфере изучения языков гбая, которые в течение нескольких десятилетий изучаются французским исследователем Ивом Моньино [Moñino 1980, 1981, 1988]. В 1995 г. была опубликована его фундаментальная монография [Моñino 1995] с изложением детального сравнительного анализа языков гбая и реконструкцией праязыка группы - его фонологической структуры, основ морфологии, значительного объёма лексики (более 1000 единиц), в том числе и субъектных личных местоимений.

К настоящему времени относительно неплохо описаны близкородственные языки группы банда, однако специального сравнительного исследования по ним не существет; с точки зрения типологии и лексических соответствий языки банда затрагиваются в работе [Olson 1996].

Монография Х. Паш [Pasch 1986] содержит качественный сравнительный анализ именной морфологии (прежде всего систем именных классов) в языках группы мба, за которым следуют выводы о внутренней классификации языков группы. Из личных показателей в работе рассмотрены только притяжательные аффиксы, их сравнения по различным языкам группы не проводится.

Языки группы сере исследовались в сравнительной перспективе С. Сантандреа, однако его итоговая работа [Santandrea 1950] довольно поверхностна и ограничивается лексическими сопоставлениями; что же до местоимений, то её автор не углубляется дальше постулирования типологических сходств вроде наличия противопоставления эксклюзивных и инклюзивных форм [Santandrea 1950: 47-48]. Работой А. Н. Такера полувековой давности [Tucker 1959] исчерпывается, к сожалению, и список сравнительных исследований языков группы занде. Реконструкции праформ в ней не проводится, хотя следует признать, что фактический материал по местоименным системам в указанной работе дан весьма подробно.

В своей статье [Boyd 1989] Р. Бойд предложил реконструированные формы четырёх местоимений праязыка адамауа-убанги [1989: 207], однако обоснования реконструкции в работе представлено не было. На сегодняшний день это, видимо, единственная попытка реконструкции личных местоимений более высокого хронологического уровня, чем уровень групп языков.

Системы личного маркирования языков убанги характеризуются следующими особенностями.

В большинстве групп семьи проводится противопоставление местоимений 1PL по категории инклюзивности / эксклюзивности (банда, нгбанди, нгбака-мба, занде). Особенностью данной категории является её факультативное дополнение значением двойственного числа. Так как это последнее жёстко ограничено первым лицом и повсюду сопутствует клюзивности, есть смысл (как и во многих других группах языков субсахарской Африки) не рассматривать категорию клюзивности и значение дуалиса по отдельности, а объединять их в единую грамматическую категорию расширенного первого лица, которая, по терминологии М. Сисоу [Cysouw 2003], имеет три значения: дуалис, инклюзив и эксклюзив. Таким образом, при наличии такой категории в местоименной системе присутствуют два или три перечисленных значения, при отсутствии - только нейтральное местоимение 1PL, но никогда иначе. Кроме того, формы инклюзива и дуалиса в различных родственных языках обычно имеют единое происхождение: так, форма 1DU линда д̀zá соответствует инклюзивным формам близкородственных языков, в то время как форма 1DU бака $2 \bar{a}$, напротив, единого происхождения с эксклюзивными местоимениями других языков убанги. 
Центральноафриканский ареал, занятый в т. ч. носителями языков убанги, в этом смысле является одним из трёх ареалов субсахарской Африки (наряду с крайним Западом и Кордофаном), где распространена данная категория. При этом, как будет показано ниже, категория расширенного первого лица вполне может быть прослежена до праязыка по крайней мере одной из групп в составе убангийской семьи.

Субъектные показатели в глагольном предложении располагаются перед глагольной группой (имеющей схему VO) и в ряде языков функционируют как глагольные префиксы. Положение объектных показателей - постпредикативное, в некоторых языках они суффигируются к сказуемому. Суффиксальными в большинстве своём являются и показатели притяжательности. В неглагольном предложении, а также в значениях фокуса и топика употребляются субъектные местоимения серии, которую мы в настоящей работе называем фокализованной (в литературе по убангийским языкам такие местоимения принято также называть «аппозитивными» [Moñino 1988, 1995]).

Для убангийских языков характерно выражение различных значений личного показателя одного лица и числа с помощью единой формы местоимения. Наиболее маркированными в этом смысле являются формы фокализованных личных местоимений, которые в целом ряде языков образованы от субъектно-объектных форм путём редупликации (нгбугу mо 'ты', mјту 'ты' (фокал.)) или добавления префигированного вокалического элемента (линда b̀̀ 'я’, д̀bà 'я’ (фокал.)). В тех языках, где объектные (а вместе с ними чаще всего и притяжательные) показатели лица отличаются от субъектных, они либо редуцированы (бофи $m \bar{\imath}$ 'я', -m 'меня, мой'), либо образованы от супплетивной основы (занде то̀ 'ты', -rò 'тебя'). В редких случаях супплетивная основа применяется при образовании притяжательных аффиксов: наиболее интересен пример 2SG посессивных маркеров в языках банда, имеющих корень $z \grave{\partial} / z \bar{a}$ при $m V / b V$ в прочих сериях. Языков, где, подобно банту, различались бы четыре различных серии личных показателей, среди убангийских языков не обнаруживается.

В отдельных языках можно видеть перенос видовременных или модальных значений сказуемого на субъектные личные показатели, что приводит к появлению новых форм, преимущественно различающихся только тональным рисунком (например, якома mbi 'я’ (PRES, PF) vs. mbí ‘'я' (FUT)).

Притяжательные показатели различают категорию отчуждаемой / неотчуждаемой принадлежности - это различие проводится повсюду в языках групп гбая и занде, а также в языке гбайи (группа нгбанди). При этом посессивная словоформа неотчуждаемой принадлежности (для имён существительных, выражающих ближайших родственников и части тела) строится в формате схемы «именная группа + суффиксальный личный показатель», значение же отчуждаемой принадлежности требует конструкции «именная группа + несвязанный атрибутивный маркер + суффиксальный личный показатель». Атрибутивный маркер является общим для всех лично-числовых значений и в зарубежных работах чаще всего называется «детерминативом» [Moñino 1995: 82]). Именные генитивные (в т. ч. посессивные) синтаксические группы строятся аналогичным образом: соположением имён существительных при неотчуждаемой принадлежности и с помощью маркера со значением отчуждаемой принадлежности.
(1) wō kpà pālā gālā
3SG чесать кожа нога
(2) ìzō rí mbàlà
экскремент GEN слон
'Он чешет ногу' (букв. 'кожу ноги');
‘экскременты слона' [Boyd 1988: 44-45].

Среди атрибутивных маркеров, используемых в языках гбая, можно выделить *kó (с общегенитивным значением), “dàà (с ассоциативным значением) и *nè (с комитативным 
значением); все три восходят к праязыку группы. В некоторых языках при присоединении показателей лично-числовых значений к генитивному маркеру происходит фузия, ср. гбану

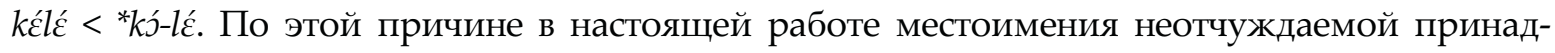
лежности будут даны в таблицах в полном виде, хотя в большинстве языков их довольно легко можно разложить на неличный генитивный маркер и собственно личный показатель.

Схожее противопоставление прослеживается в объектной серии личных показателей: во многих из рассмотренных нами языков проводится различие между показателями прямого и непрямого объекта. В частности, наиболее последовательно данное различие выражено в группе гбая, однако отмечено также в языках групп занде и нгбанди. В языках гбая показатели непрямого объекта образованы добавлением личного объектного суффикса к дативно-бенефактивному маркеру *há- 'для, к’ [Moñino 1995: 160].

(3) $\quad n d \dot{\varepsilon} \quad$ wá $g b \varepsilon \dot{\varepsilon}-m$

CONJ 3PL.S убивать.PROSP-1SG.DO

'Они собираются убить меня';

(4) me tó yege né é ha túrú hám

2SG.S сказать QUOT CONJ CONJ давать одежда 1SG.IO

‘Ты сказал, что дашь мне одежду’ [Samarin 1966: 104, 106].

Слитный показатель непрямого объекта в примере (4) является результатом грамматикализации послеложной группы, которая ещё отчётливо видна в других группах убангийских языков (например, в группе занде), где непрямообъектная группа строится с помощью контаминированных послелога и личного показателя, ср. в нзакара:

(5) mó-ít-ê

2SG.S-оставить-1SG.O

'Оставь меня!'

(6) kó-hú pàmba n-é

3SG.M-давать нож PP-1SG.O

‘Он дал мне нож’ [Tucker 1959: 131].

Пичные показатели в языках убанги имеют в основном структуру CV, в редких случаях V. Показатели отчуждаемой принадлежности и непрямообъектные маркеры, образованные путём добавления собственно личного показателя к показателю посессивности, могут иметь двусложную структуру CVCV (например, бозом ká-ré 'наш’ (отчужд.)) и даже трёхсложную CVCVCV. Такая же силлабическая структура типична для тех показателей фокализованной серии, которые образованы с помощью удвоения (например, линда $2 \bar{e} 2 \bar{e}$ (вы’). Характерной особенностью личных показателей множественного числа в убангийских языках является их дисиллабическая структура - вида VCV или, чаще, ?VCV. При этом в объектных формах мы нередко видим форму без ларингального приступа и вокалического префикса: бофи $2 \bar{\varepsilon} l \bar{\varepsilon}$ 'мы' (субъект) и $l \bar{\varepsilon}$ 'мы' (объект), $2 \bar{\varepsilon} n \bar{\varepsilon}$ 'вы' (субъект) и $n \bar{\varepsilon}$ 'вы' (объект). О природе ларингальной фонемы в личных показателях убангийских языков будет сказано ниже.

Показатели третьего лица в убангийских языках по своему происхождению и особенностям функционирования в языке несколько отличаются от местоимений двух первых лиц. В первую очередь стоит отметить их бросающуюся в глаза разнородность (см. 
таблицы раздела 5): при очевидных следах генетического родства показателей первых двух лиц представляется невозможным реконструировать для праязыка убанги формы третьего лица. Отдельные реконструкции возможны лишь на уровне групп языков.

Необходимо отметить возможную связь между личными показателями третьего лица и маркерами именных классов, характерную для языков нигеро-конголезской макросемьи. В языках бенуэ-конго, ква, гур и других семей языков субсахарской Африки третье лицо маркируется показателями именных классов имени существительного; таким образом, могут выделяться отдельные показатели для лиц, животных, неодушевлённых предметов, принадлежащих различным классам.

Системы именных классов характерны лишь для некоторых убангийских языков (наиболее отчётливо в группе мба, см. [Pasch 1986]) и в целом ряде случаев представляют собой инновацию [Boyd 1989: 205]. Новую именную классификацию мы видим, к примеру, в языках группы занде, имеющих в единственном числе до четырёх различных показателей третьего лица: для обозначения мужчин, женщин, животных и неодушевлённых предметов; во множественном числе различие мужского и женского рода элиминируется [Tucker 1959: 118, 129 и след.]. Формы показателей при этом имеют краткую фонетическую форму, что не позволяет этимологизировать их из именных источников. Ранее выдвигалось предположение о происхождении местоимений третьего лица в занде из именных основ типа ‘человек' и ‘вещь' [Claudi 1985], однако эта гипотеза выглядит весьма натянутой именно из-за умозрительности постулируемых фонетических преобразований и требует более глубокой доказательной базы, так как известно, что типологически подобное происхождение местоимений третьего лица вполне возможно [Бабаев 2009]. В некоторых языках именное происхождение местоимений 3 лица можно предполагать, исходя из набора синтаксических функций последних, весьма близких к функциям имени (подробнее об этом см. ниже).

Стоит отметить, наконец, что во многих языках убанги местоимения третьего лица дополнены логофорическими. В некоторых случаях их происхождение довольно древнее: так, в языках группы гбая логофорические местоимения функционируют почти повсеместно, что позволило И. Моньино восстановить этот подкласс местоимений для праязыка группы:

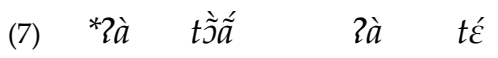

3SG сказать 3SG приходить

'Он [актант -1] сказал, что он [актант-2] пришёл';

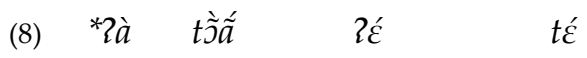

3SG сказать 3SG.LOG приходить

‘Он [актант -1] сказал, что он [актант-1] пришёл’ [Moñino 1995: 422].

На этом мы завершаем общую характеристику систем личных показателей в убангийских языках и можем перейти непосредственно к сравнительному анализу форм, представленных в приводимых ниже сводных таблицах $(1,4,7,9,11,13)$. В них формы через запятую представляют собой диалектные варианты или же варианты, обнаруженные в различных работах по данному языку (различие между ними могут объясняться как диалектологией, так и обычными ошибками при записи). Там, где между вариантами можно отследить грамматические различия, значения указаны в круглых скобках. Знаком косой черты разделены варианты формы одного значения, указанного в скобках вслед за последним из них. 
Языки в таблицах сортированы по группам, обозначенным следующими аббревиатурами: Б - банда, Г - гбая, Нд - нгбанди, Нк - нгбака, М - мба, С - сере, 3 - занде.

Аббревиатуры, использованные для языков, названных по сторонам света, расшифровываются стандартно: С3 - северо-западный, Ю3 - юго-западный, ЗЦ - западноцентральный, ЮЦ - южно-центральный.

Данные детализированы по диалектам там, где диалектные формы имеют характерные отличия. В таких случаях названия языка и диалекта приведены в левом столбце таблицы через дефис, например, «моно-били» - диалект били языка моно.

Источники данных указаны в квадратных скобках в примечаниях к Таблице 1.

\section{1-е дицо единственного числа}

Таблица 1

\begin{tabular}{|c|c|c|c|c|}
\hline & субъект & объект & притяжат. & фокал \\
\hline мбрес (Б) ${ }^{1}$ & $m \bar{\partial}$ & $m \bar{\partial}$ & & \\
\hline ЗЦ-дакпа (Б)² & $m e ̀, m i$ & mé, mi & mé, mi & èmé \\
\hline ЗЦ-гби (Б) $)^{2}$ & $m \bar{e}$ & $m \bar{e}$ & & \\
\hline ЗЦ-уоджо (Б)² & $m \bar{a}$ & $m \bar{e}$ & & \\
\hline банда (Б) ${ }^{3}$ & $m \bar{\partial}$ & $m \bar{\partial}$ & & \\
\hline ЮЦ-лангба (Б) & $m \bar{e}$ & $m \bar{e}$ & & \\
\hline ЮЦ-нгбугу (Б)² & $m \bar{\imath}, m i ́, m \bar{e}$ & mí & mí & mìmí \\
\hline лангбаше (Б) ${ }^{3}$ & $m \bar{e}, m i$ & $m \bar{e}, m i$ & $m i$ & \\
\hline бамбари (Б) $)^{2}$ & $m \bar{a}$ & $m \bar{a}$ & $m \bar{a}$ & $\bar{\partial} m \bar{\partial}$ \\
\hline мбанджа (Б) & $m e ́, m \bar{\varepsilon}$ & $m e ́, m \bar{\varepsilon}$ & & \\
\hline нделе (Б) ${ }^{3}$ & $m \bar{a}$ & $m \bar{a}$ & & \\
\hline вара (Б) $)^{2}$ & $m \bar{e}$ & $m \bar{e}$ & & \\
\hline ср.-юж. (Б) $)^{2}$ & $m \bar{a}$ & $m \bar{a}$ & & \\
\hline янгере (Б) $)^{2}$ & $m \bar{o}$ & $m \bar{o}$ & & \\
\hline моно (Б) ${ }^{4}$ & $m i$ & $m i$ & $m i$ & \\
\hline моно-били (Б) & $m \bar{a}$ & $m \bar{a}$ & $m \bar{a}$ & $\bar{\partial} m \bar{\partial}$ \\
\hline С3-кара $(\Gamma)^{6}$ & Zám & $-m,-m i ́$ & $\begin{array}{l}-m,-m i ́(\mathrm{INAL}), k j ́ m \\
(\mathrm{AL})\end{array}$ & mí \\
\hline С3-яювее $(\Gamma)^{7}$ & mí & $-m,-m i ́$ & $\begin{array}{l}-m,-m i ́(\mathrm{INAL}), k o ́ m \\
(\mathrm{AL})\end{array}$ & mí \\
\hline С3-лаи $(Г)^{8}$ & mí & $m i ́,-m$ & -m (INAL), kóm (AL) & mí \\
\hline Ю3-були $(\Gamma)^{8}$ & Zín, mí & $m i ́$ & -môy (INAL), bò (AL) & $m i ́$ \\
\hline
\end{tabular}

${ }^{1}$ [Segerer 2002-2007].

${ }^{2}$ [Tisserant 1930; Segerer 2002-2007].

${ }^{3}$ [Sampson 1997; Segerer 2002-2007].

${ }^{4}$ [Tisserant 1930: 39-48].

${ }^{5}$ [Olson 2001: 85].

${ }^{6}$ [Roulon-Doko 1993; Moñino 1995: 75-76].

7 [Moñino 1995].

8 [Boyd 1997: 66-70; Moñino 1995: 130]. 


\begin{tabular}{|c|c|c|c|c|}
\hline & субъект & объект & притяжат. & фокал. \\
\hline Ю3-тоонго $(\Gamma)^{8}$ & $m i ́$ & mí & -mí (INAL), bòy (AL) & mí \\
\hline Ю3-биянда $(\Gamma)^{8}$ & $m i ́$ & mí & $\begin{array}{l}\text {-mí (INAL), pj̀m(í) / } \\
\text { póm (AL) }\end{array}$ & \\
\hline мбодомо $(\Gamma)^{8}$ & $m i ́$ & $m i$ & -mí (INAL), bòy (AL) & $m i$ \\
\hline бокото $(\Gamma)^{8}$ & Zám & $-(a ́) m$ & $\begin{array}{l}-(a ́) m \text { (INAL), kóm } \\
(\mathrm{AL})\end{array}$ & mí \\
\hline бозом $(\Gamma)^{8}$ & mí, Zám, mám & $-m$ (DO), hám (IO) & $-m$ (INAL), kóm (AL) & \\
\hline босангоа $(\Gamma)^{8}$ & 2àm (IPF), rám (PF) & -m (DO), hám (IO) & $-m$ (INAL), kóm (AL) & $m i ́$ \\
\hline гбану $(\Gamma)^{8}$ & mí & $\begin{array}{l}-m \text { / mí (DO), hóm } \\
(\mathrm{IO})\end{array}$ & $\begin{array}{l}\text {-m / mí (INAL), kóm / } \\
\text { dààmí / nǒm (AL) }\end{array}$ & \\
\hline али $(\Gamma)^{8}$ & $m \bar{\imath}$ & $m \bar{\imath}$ & $\begin{array}{l}m \bar{\imath} \text { (INAL), kómī / } \\
d \bar{a} m \bar{\imath}(\mathrm{AL})\end{array}$ & \\
\hline манза $(\Gamma)^{8}$ & $2 \bar{e}$ & $m \bar{\imath}(\mathrm{DO}), h \hat{a} \tilde{a}$ (IO) & 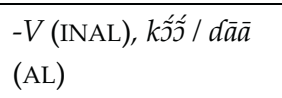 & $m \bar{\imath}$ \\
\hline нгбака $(\Gamma)^{8}$ & $\imath \bar{\varepsilon}, m \bar{\imath}$ & $\begin{array}{l}m \bar{\imath}(\mathrm{DO}), h \tilde{a} / \text { hám } \bar{\imath} \\
(\mathrm{IO})\end{array}$ & 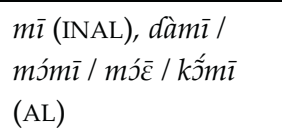 & \\
\hline бофи $(\Gamma)^{8}$ & $m \bar{\imath}$ & $-m$ (DO), hām (IO) & $\begin{array}{l}-m \text { (INAL), nàām / } \\
k \hat{\jmath} m \text { (AL) }\end{array}$ & \\
\hline банганду $(\Gamma)^{8}$ & $m i ́$ & mí (DO), hámí (IO) & $m u ́$ & \\
\hline якома $\left(\mathrm{Hд}^{9}\right.$ & $m b i, m b i ́(\mathrm{FUT})$ & & & $m b \bar{\imath}$ \\
\hline гбайи (Нд) $)^{10}$ & $m \bar{\imath}, m \bar{e}$ & & $-m \bar{e}(\mathrm{INAL}),-c \grave{a}(\mathrm{AL})$ & \\
\hline мунду (Нк) & $m a ́, m o ́$ & $r \bar{\varepsilon}, r \bar{a}$ & $r \bar{\varepsilon}, r \bar{a}$ & $r \bar{\varepsilon}, r \bar{a}$ \\
\hline нгбака-мабо (Нк) $)^{12}$ & $m \bar{a}$ & & & \\
\hline монзомбо $(\mathrm{Hк})^{14}$ & $m \bar{a}$ & & & \\
\hline гбанзири $(\mathrm{Hк})^{13}$ & $m a ́, m \bar{a}$ & & & \\
\hline бака $(\mathrm{Hк})^{14}$ & $m \bar{a}$ & & & $\eta \bar{a} \grave{a}$ \\
\hline майого (Нк) & $-m \bar{a}$ & & & \\
\hline ндунга (M) & $n \bar{\varepsilon}$ & $m>(\mathrm{IO})$ & $n \grave{e}$ (INAL), nc̀ (AL) & \\
\hline мба (M) ${ }^{16}$ & nó & & -éà, $-\hat{a}$ & \\
\hline донго-ко $(\mathrm{M})^{16}$ & $d \grave{\varepsilon}, r \grave{\varepsilon}$ & & $d \hat{\varepsilon}, r \grave{\varepsilon}$ & \\
\hline ма $(\mathrm{M})^{16}$ & $m \tilde{\bar{u}}, m \grave{u}-$ & & & \\
\hline cepe $(\mathrm{C})$ & $y \bar{e}$ & & & \\
\hline баи (C) & $n \bar{e}$ & & & \\
\hline занде $(3)^{16}$ & $m i$ & rè, -ré & $m i$ (INAL), glmi (AL) & $m i, m i$ \\
\hline
\end{tabular}

${ }^{9}$ [Boyeldieu 1995].

${ }^{10}$ [Boyd 1988].

${ }^{11}$ [Vallaeys 1991].

${ }^{12}$ [Moñino 1988].

${ }^{13}$ [Boyd 1978: 75; Moñino 1988].

${ }^{14}$ [Brisson \& Boursier 1979].

${ }^{15}$ [Pasch 1986; Moñino 1988].

${ }^{16}$ [Tucker 1959; Segerer 2002-2007]. 


\begin{tabular}{|c|c|c|c|c|}
\hline & субъект & объект & притяжат. & фокал. \\
\hline барамбу (3) $)^{17}$ & nó, n-, nú, -na & $\begin{array}{l}\text {-nò (DO), -erè / -érè / } \\
\text {-re (IO) }\end{array}$ & $\begin{array}{l}\text {-ére / -éré / -erì / -eri } \\
\text { (INAL), gyèrè / gyere / } \\
\text { gere / šiere / zegyère } \\
\text { (AL) }\end{array}$ & \\
\hline памбиа (3) $)^{18}$ & ni, né, ní, -né & $-\eta \grave{~}$ & $\begin{array}{l}\text {-nè / lyè / -je (INAL), } \\
\text { aje / alye (AL) }\end{array}$ & né, ní \\
\hline геме $(3)^{19}$ & mì & & & \\
\hline нзакара (3) & $m i, m i$ & $-\grave{e}$ & & $m i, m i$ \\
\hline
\end{tabular}

Как и в других языках мира, местоимения 1SG являются наиболее стабильным членом парадигмы, и праформы здесь восстанавливаются относительно легко. В качестве общей для подавляющего большинства языков семьи схемы субъектного показателя можно назвать $m V-$ сочетание губной носовой согласной с некоторой гласной. Вокалический элемент преимущественно принадлежит переднему ряду: в языках банда это $i, e$, а также редуцированная гласная среднего ряда ә, которую логично рассматривать как происходящую из * $i$ / *е в результате ослабления гласной фонемы, но не наоборот, так как для сдвига праязыковой гласной вперёд никаких фонетических оснований не находится. Редукции гласной не происходит в суффиксальном объектном показателе в языках сев. гбага и уоджо, где огласовка переднерядная: тё.

В языках групп гбая и нгбанди повсюду видим гласную -i, а в занде -ı. Заднерядная гласная может быть восстановлена только для праязыка группы нгбанди. Здесь можно предположить развитие, аналогичное языкам банда: ослабление переднеязычной гласной до а и последующий переход среднерядной фонемы в $a-$ возможно, под влиянием форм 2SG, ср. мунду та́ 'я', mà 'ты'.

Форма 2am, распространённая в западных и северных языках гбая, выступает в большинстве идиомов не как самостоятельное местоимение, а как субъектный префикс глагола [Moñino 1995: 421]. Данная морфема представляет собой композит, состоящий из $2 a-$ и личного показателя $-m$. Его образование сравнительно недавнее, а генезис можно легко проследить на материале современных диалектов гбая [Noss 1969: 24]: в быстрой речи (язык кара) гласная местоимения ті́ редуцируется, так что фраза mí kõ ná 'я не хочу' произносится как [ḿkś ná], после чего во избежание произнесения неизвестного языкам убанги начального кластера добавляется эвфонический префикс $2 a-$.

Показатель ní- / ле́- в языке памбиа (группа занде) также со всей вероятностью представляет собой рефлекс основы на *m-: видно, что делабиализация происходит не только в этой форме, но и в показателе 2SG үо (см. ниже).

Таким образом, наиболее вероятным вариантом для праязыковой реконструкции остаётся вариант *mi. Тон праязыкового показателя восстановить сложно: в языках банда, нгбанди и нгбака преобладает средний, в гбая реконструируется высокий, а для языков занде - низкий тон.

Субъектные показатели языков сере и нгбака-мба происходят из других лексических основ. Формы двух языков группы сере $n \bar{e}$ и уё, по-видимому, происходят из единого источника. То же можно сказать о двух близкородственных языках группы мба - ндунга и донго-ко: формы $n \bar{\varepsilon}$, $d \grave{\varepsilon}$ и $r \grave{\varepsilon}$ представляют собой очень распространённое в африканских

\footnotetext{
17 [Tucker 1959; Boyd \& Nougayrol 1988].

18 [Tucker 1959: 223-226; Boyd \& Nougayrol 1988].

19 [Boyd \& Nougayrol 1988].
} 
языках чередование согласных. Общее происхождение форм сере и мба на имеющемся материале ничем не подкрепляется, так что имеет смысл рассматривать их пока как групповые инновации.

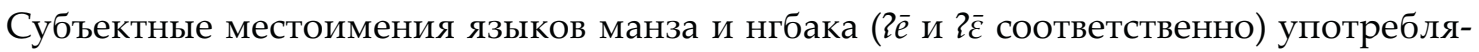
ются наравне с $m \bar{l}$, а в манза - даже в большем количестве контекстов. Однако здесь можно постулировать сравнительно позднее замещение исконного местоимения $m \bar{\imath}$, исходя из того, что в нгбака $2 \bar{\varepsilon}$ тяготеет к употреблению в косвенной речи [Moñino 1995: 242]. Наиболее вероятным кажется происхождение данной формы из логофорического местоимения *ใé [Moñino 1995: 422] с заменой исходного высокого тона на средний тон, характерный для местоимений 1SG.

В большинстве рассматриваемых языков показатели всех четырёх значений совпадают или же различаются лишь огласовкой или тоном. Эти различия часто вызваны различными позициями показателей в словоформе или предложении. Там, где показатель фокализованного актанта выделяется своей формой, можно отметить некоторые закономерности. Так, в языках банда фокализованные местоимения с вокалическим префиксом явно восходят к праязыковому состоянию: е̄mé / д̄mō. Тон вокалического аугмента в большинстве языков ассимилируется с тоном местоимения по всей парадигме [Olson 2001: 85].

В притяжательной и объектной сериях, представленных в большинстве языков убанги суффиксальными показателями, напротив, может происходить редукция первоначальной формы до -m (группа языков гбая). В нескольких языках семьи, принадлежащих к различным группам (мунду, донго-ко, занде, барамбу) притяжательные, а иногда и объектные показатели образованы с помощью генитивного маркера ri / re / re. Это происхождение можно, скорее всего, постулировать также для показателя отчуждаемой принадлежности гбайи -са̀, исходя из того, что генитивный маркер ri эксплицитно присутствует в других формах парадигмы (Таблица 2) и функционирует в именных конструкциях отчуждаемой принадлежности (см. пример (2) выше) [Boyd 1988: 45].

\begin{tabular}{|c|c|c|}
\hline & SG & PL \\
\hline 1 & $-c a ̀$ & -rí-nì \\
\hline 2 & $-c \hat{\jmath}$ & -rí-mj̀ \\
\hline 3 & $-r i ̀$ & -r(í)-álà \\
\hline
\end{tabular}

Таблицุа 2

Исходя из вышесказанного, мы можем с большой долей уверенности реконструировать для праязыка семьи убанги одну форму личного местоимения 1sG *mi. Реконструкции праязыковых форм по некоторым группам приведены в Таблице 3.

\begin{tabular}{l|l}
\hline банда & *mā \\
\hline гбая & *mí \\
\hline нгбанди & *mī \\
\hline нгбака & *mā \\
\hline занде & *mì \\
\hline убанги & *mi \\
\hline
\end{tabular}


Реконструкция *mi хорошо соотносится с праформами, восстанавливаемыми для других семей языков нигер-конго; прямые соответствия имеются в бенуэ-конго (в том числе банту), ква, адамауа, гур, догон, большинстве групп атлантических языков. Таким образом, проведённая нами внутренняя реконструкция вполне подтверждается данными внешнего сравнения.

\section{2-е дицо единственного числа}

Таблицุа 4

\begin{tabular}{|c|c|c|c|c|}
\hline & субъект & объект & притяжат. & фокал. \\
\hline мбрес-бука (Б) & bà & bà & & \\
\hline мбрес-мбере (Б) & $6 \grave{~}$ & $6 \grave{\partial}$ & & \\
\hline ЗЦ-дакпа (Б) & mò & $m \bar{a}, m o$ & $z \bar{a}$ & òmā \\
\hline ЗЦ-гби (Б) & mà & mà & & \\
\hline ЗЦ-гбага (Б) & mà & mà & & \\
\hline банда (Б) & bà & bà & & \\
\hline ЮЦ-лангба (Б) & mò & mò & & \\
\hline ЮЦ-нгбугу (Б) & $m o$ & $m \bar{\jmath}$ & $z \bar{\partial}, z \grave{\partial}$ & mòm̄̄, mòmō \\
\hline лангбаше (Б) & mà, mo & mà, mo & & \\
\hline бамбари (Б) & bà & bà & $z \grave{\partial}$ & àbò \\
\hline мбанджа (Б) & mà & mà & & \\
\hline нделк (Б) & bà & bò & & \\
\hline вара (Б) & bò & bò & & \\
\hline ср.-юж. (Б) & bà & bà & & \\
\hline янгере (Б) & bà & bà & & \\
\hline моно (Б) & mo & mo & & \\
\hline моно-били (Б) & bà & bà & zà & àbà \\
\hline С3-кара (Г) & $m \varepsilon ́$ & $m \varepsilon ́$ & $\begin{array}{l}\text {-mé (INAL), kómé } \\
(\mathrm{AL})\end{array}$ & $m \varepsilon ́$ \\
\hline С3-лаи (Г) & $m \varepsilon ́$ & $m \varepsilon ́$ & $\begin{array}{l}\text {-mé (INAL), kómé } \\
(\mathrm{AL})\end{array}$ & $m \varepsilon ́$ \\
\hline Ю3-були (Г) & $m \varepsilon ́$ & $m \varepsilon ́$ & $-m \varepsilon ́(\mathrm{INAL}), b \grave{\varepsilon}(\mathrm{AL})$ & $m \varepsilon ́$ \\
\hline Ю3-тоонго (Г) & $m \varepsilon ́$ & $m \varepsilon ́$ & 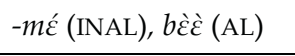 & $m \varepsilon ́$ \\
\hline Ю3-биянда (Г) & $m \varepsilon ́$ & $m \varepsilon ́$ & $\begin{array}{l}\text {-mé (INAL), pèmé } \\
(\mathrm{AL})\end{array}$ & \\
\hline мбодомо (Г) & $m \varepsilon ́$ & $m \varepsilon \dot{c}$ & -mé (INAL), mè (AL) & \\
\hline бокото $(\Gamma)$ & $m \varepsilon ́$ & $m \varepsilon ́$ & $\begin{array}{l}\text {-mé (INAL), kómé } \\
\text { (AL) }\end{array}$ & \\
\hline бозом $(\Gamma)$ & $m \varepsilon ́$ & mé (DO), hámé (IO) & $\begin{array}{l}-m \varepsilon ́ \text { (INAL), kómé } \\
(\mathrm{AL})\end{array}$ & \\
\hline босангоа $(\Gamma)$ & $m \varepsilon \grave{~(I P F), ~ m \varepsilon ́ ~(P F) ~}$ & mé (DO), hámé (IO) & -mé (INAL), kómé (AL) & $m \varepsilon ́$ \\
\hline гбану (Г) & $m \varepsilon ́$ & $m \varepsilon ́(\mathrm{DO})$, hómé (IO) & $\begin{array}{l}\text { mé (INAL), kómé / } \\
\text { dààmé / nذ̀mé (AL) }\end{array}$ & \\
\hline
\end{tabular}




\begin{tabular}{|c|c|c|c|c|}
\hline & субъект & объект & притяжат. & фокал. \\
\hline али $(\Gamma)$ & $m \bar{\varepsilon}$ & $m \bar{\varepsilon}$ & $\begin{array}{l}m \bar{\varepsilon}(\mathrm{INAL}), k j ́ m \bar{\varepsilon} / \\
\operatorname{dām} \bar{\varepsilon}(\mathrm{AL})\end{array}$ & \\
\hline манза $(\Gamma)$ & $m \bar{\varepsilon}$ & $m \bar{\varepsilon}(\mathrm{DO}), h \tilde{a} m \bar{\varepsilon}(\mathrm{IO})$ & $\begin{array}{l}m \bar{\varepsilon}(\mathrm{INAL}), k \tilde{\jmath} m \bar{\varepsilon} \\
\operatorname{da} m \bar{\varepsilon}(\mathrm{AL})\end{array}$ & \\
\hline нгбака $(Г)$ & $m \bar{\jmath}, m \grave{\jmath}$ (IMP) & $m \bar{\jmath}(\mathrm{DO}), h \tilde{a} m \bar{\jmath}(\mathrm{IO})$ & 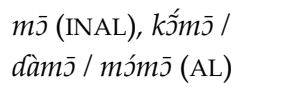 & \\
\hline бофи (Г) & $m \bar{\varepsilon}$ & $m \bar{\varepsilon}(\mathrm{DO}), h \bar{a} m \bar{\varepsilon}(\mathrm{IO})$ & $\begin{array}{l}m \bar{\varepsilon}(\mathrm{INAL}), n a ̀ m \bar{\varepsilon} / \\
k j m \bar{\varepsilon}(\mathrm{AL})\end{array}$ & \\
\hline банганду (Г) & $m \varepsilon ́$ & mé (DO), hámé (IO) & $m \varepsilon ́$ & \\
\hline якома (Нд) & mó, mò & & & $m \grave{~}$ \\
\hline гбайи (Нд) & mò & & $-m \grave{\jmath}(\mathrm{INAL}),-c \hat{\jmath}(\mathrm{AL})$ & \\
\hline мунду (Нк) & mà, mò, mù & mà, mò, mù & mà, mò, mù & dēmò \\
\hline нгбака-мабо (Нк) & $m \tilde{o}$ & & & \\
\hline монзомбо (Нк) & $m \tilde{o}$ & & & \\
\hline гбанзири (Нк) & 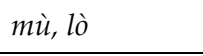 & & & \\
\hline бака (Нк) & mò & & & \\
\hline майого (Нк) & $-m u ̀ ~$ & & & \\
\hline ндунга (М) & $m \bar{o}$ & & & \\
\hline мба (M) & mò, mó & & $-u ́ j$ & mò \\
\hline донго-ко (М) & dǒ & & $z \grave{o}$ & \\
\hline ма (M) & mūij́ & & & \\
\hline cepe $(\mathrm{C})$ & $w \bar{o}$ & & & \\
\hline баи $(\mathrm{C})$ & $\eta \bar{o}$ & & & \\
\hline занде (3) & mò & -rò & $\begin{array}{l}\text {-mó (INAL), -gamó } \\
(\mathrm{AL})\end{array}$ & mò \\
\hline барамбу (3) & mú, mò-, -ómú & $\begin{array}{l}\text {-mo / -mu (DO), (o)rò } \\
\text { / órò (IO) }\end{array}$ & $\begin{array}{l}\text {-óro / -ró / -rò (INAL), } \\
\text { gòrò (AL) }\end{array}$ & \\
\hline памбиа (3) & ๆo- & $-\eta о$ & $\begin{array}{l}-\eta o /-w o \text { (INAL), awo } \\
(\mathrm{AL})\end{array}$ & ๆo \\
\hline геме (3) & $m \grave{~}$ & & & \\
\hline нзакара (3) & mò, mo- & -ó & $-m o$ & $m \grave{~}$ \\
\hline
\end{tabular}

Характерным является почти повсеместное распространение модели $m V$ с широкой гласной фонемой. Эта модель является базовой для языков групп банда, гбая, нгбанди, нгбака, мба и занде. Тем не менее, реконструкция единой праформы наталкивается на ряд существенных трудностей.

Языки банда демонстрируют гласную среднего ряда и подъёма (т. н. «неопределенную») -д. Эта же гласная, как можно видеть выше, присутствует в формах 1SG, создавая, таким образом, в целом ряде языков омофонию двух показателей с различными значениями. Можно показать, однако, что по крайней мере в одном из языков банда неопределённая гласная может являться результатом редукции двух различных фонем в формах 1 и 2 лица. Это язык моно: данные Ш. Тиссерана первой половины XX века [Tisserant 1930: 40] демонстрируют формы mi ‘я’ и то 'ты’ с различными огласовками, обеим в со- 
временной нам работе [Olson 2001: 85] соответствует д. Не исключено, что две указанных работы используют данные различных диалектов (у К. Олсона это диалект били, диалект данных Тиссерана не указан), но соответствие двух различных гласных и «шва»в любом случае неоспоримо.

Устранение омонимии показателей двух лиц в языках банда после редукции гласных достигалось двумя способами: тональным противопоставлением (средний тон показателей 1SG vs. низкий тон показателей 2SG) и деназализацией губной носовой: $m>b / 6$. В результате второго процесса появляются инновационные формы $b \grave{\text { / }}$ б̇̀, нехарактерные для других групп убангийских языков. Данная инновация присуща в основном идиомам периферии ареала, занятого языками банда, в то время как языки центра этого ареала (собственно язык банда, а также западно-центральные диалекты и лангбаше) демонстрируют $m-$.

Формы *mo / *mо реконструируются также для праязыков групп нгбанди, нгбака, занде, возможно, также мба. Форма *mиे является результатом лабиализации исходной гласной в двух близкородственных языках нгбака - гбанзири и майого. Наконец, данные языков группы гбая позволяют уверенно восстановить праформу *mé [Moñino 1995: 421] как для субъектных, так и для несубъектных значений. Аишь в языке нгбака видим местоимение $m \bar{\jmath}$, которое, по-видимому, было заимствовано из одного из соседних языков (вероятно, группы нгбанди): нгбака не имеет контактов с другими языками гбая [Моñino 1995: 228]. Истоки формы *mє́, если считать её новообразованием, неясны: одним из предположений может быть аналогия с формами множественного числа, также имеющих в языках группы гласную $\varepsilon$. Семантически это создаёт противопоставление «я - не-я», типологически весьма надёжно засвидетельствованное в языках мира. То, что в языках убанги вокализм играл важную роль в создании подобных противопоставлений, уже упоминалось выше; к примеру, местоимения 3 лица характеризуются вокализмом -à.

Таким образом, форма *mo / *mo предположительно может быть восстановлена для субъектного местоимения 2SG праязыка убанги, при том, что форма гбая *mє́ остаётся при этом загадкой.

Вопрос о том, можно ли сравнивать формы үо языков баи и памбиа с вышеприведённой реконструкцией, позволяет дать утвердительный ответ, если сравнить парадигмы местоимений в целом. Так, соответствие памбиа пі- 'я' с занде ті то же, что и между памбиа үо- с занде то̀. Схожее явление палатализации носового сонанта можно предпо-

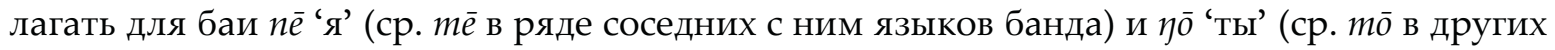
языках семьи). К сожалению, на сегодняшний день мы не располагаем достаточными данными о языках группы сере, чтобы удостоверить это фонетическое соответствие на большем количестве лексических сопоставлений, поэтому вынуждены оставить выдвинутую гипотезу неподтверждённой.

Субъектных местоимений, имеющих особое происхождение, в представленных на-

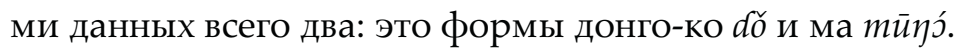

Первая содержит фонему $d$-, характерную для трёх из четырёх личных местоимений донго-ко 1-2 лица:

\begin{tabular}{|c|c|c|}
\hline & SG & PL \\
\hline 1 & $d \grave{\varepsilon}, r \grave{\varepsilon}$ & $n \grave{a}(\mathrm{I}), n \bar{\imath}(\mathrm{E})$ \\
\hline 2 & dŏ & $d \grave{a}$ \\
\hline
\end{tabular}


С учётом того, что звонкая зубная имплозивная фонема весьма нехарактерна для личных местоимений этих значений, формы с ней нужно признать инновациями. Форма тӣү́́ языка ма также инновационна: она создана, очевидно, для устранения омони-

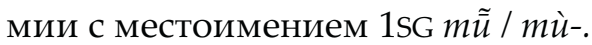

Некоторые особенности можно отметить в несубъектных сериях личных показателей. Так, притяжательный маркер 2SG в языках банда реконструируется как *zа̀. Весьма вероятно, что первоначальная гласная здесь - $a$, сохранившаяся в диалекте дакпа западноцентрального языка, но вне его подвергшаяся повсеместной редукции. Безусловно, любопытно сравнить формы языков банда с посессивным суффиксом донго-ко zò. Возможно, впрочем, что появление этого нехарактерного для убанги показателя посессивности стало результатом влияния форм 1PL инклюзива д̀zá: инклюзивное местоимение со значением «мы с тобой» вполне могло быть переосмыслено как à + zá.

Особые фокализованные формы также представлены преимущественно в языках банда. Здесь, как и по всей парадигме, используются техники префиксации и редупли-

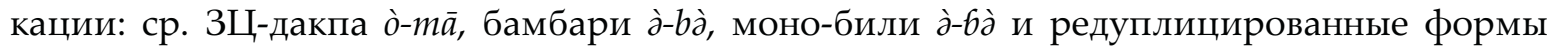
mว̀m̄ / mòmō в ЮЦ-нгбугу.

Праформы, реконструируемые нами для 2SG по отдельным группам и для убангийской семьи в целом, приведены в Таблице 6.

\begin{tabular}{l|l}
\hline банда & *mò (субъект), *zò (объект) \\
\hline гбая & *mé \\
\hline нгбанди & *mo \\
\hline нгбака & *mò / *mù \\
\hline мба & *mo / *mu ? \\
\hline занде & *mo \\
\hline убанги & *mo \\
\hline
\end{tabular}

\section{1-е лицо множественного числа}

\begin{tabular}{|c|c|c|c|c|}
\hline & субъект & объект & притяжат. & фокал. \\
\hline мбрес-бука (Б) & àzá (I), $2 \bar{a}(\mathrm{E})$ & àzá (I), $2 \bar{a}(\mathrm{E})$ & & \\
\hline мбрес-сабанга (Б) & àzá (I), $\{\bar{a}(\mathrm{E})$ & àzá (I), $\{\bar{a}(\mathrm{E})$ & & \\
\hline ЗЦ-дакпа (Б) & $\grave{a} z \bar{i}$, eze (I), a (E) & $\grave{a} z \bar{\imath}$, eze (I), $a(\mathrm{E})$ & $z a ́$ & $\grave{a} z \bar{\imath}$ \\
\hline ЗЦ-гби (Б) & $\grave{a} z \bar{e}(\mathrm{I}), \imath \bar{a}(\mathrm{E})$ & $\grave{a} z \bar{e}(\mathrm{I}), \imath \bar{a}(\mathrm{E})$ & & \\
\hline ЗЦ-гбага (Б) & $\{\grave{a}(\mathrm{I}), \imath \bar{a}(\mathrm{E})$ & ใà (I), $\{\bar{a}(\mathrm{E})$ & & \\
\hline ЗЦ-уоджо (Б) & ’̀zā (I), $\imath \bar{a}(\mathrm{E})$ & àzā (I), $\imath \bar{a}(\mathrm{E})$ & & \\
\hline банда-гбага (Б) & àzá (I), $\imath \bar{a}(\mathrm{E})$ & àzá (I), ใā (E) & & \\
\hline банда-хаи (Б) & òzá, \{à (I), \{ā (E) & àzá, ใà (I), ₹ā (E) & & \\
\hline лангбаше (Б) & $\grave{a} z \bar{\partial}, a z e(\mathrm{I}), \imath a ̀, a(\mathrm{E})$ & àzā (I), ใà (E) & & \\
\hline бамбари (Б) & àzá (DU), ใà (I), $\imath \bar{a}$ (E) & àzá (DU), $\imath \grave{a}(\mathrm{I}), \imath \bar{a}(\mathrm{E})$ & ø̀-zá (DU), $2 a ̀ ~(I), ~ \imath \overline{a ~(E) ~}$ & $\begin{array}{l}\text { àzá (DU), zàzà (I), } \\
\text { zā?ā (E) }\end{array}$ \\
\hline мбанджа (Б) & $2 \tilde{a}(\mathrm{E})$ & $2 \tilde{a}(\mathrm{E})$ & & \\
\hline
\end{tabular}




\begin{tabular}{|c|c|c|c|c|}
\hline & субъект & объект & притяжат. & фокал. \\
\hline ЮЦ-нгбугу (Б) & $\begin{array}{l}\text { àzá, àzā (I), à } \mathrm{a} \text { / āáa } \\
\text { (E) }\end{array}$ & 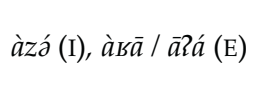 & $\begin{array}{l}\text { àzá, àzō (I), àsāa / ā?á } \\
\text { (E) }\end{array}$ & àzāzá (I), à $\overline{a ̄}$ á (E) \\
\hline нделе (Б) & $\{\grave{a}(\mathrm{I}), \imath \bar{a}(\mathrm{E})$ & ใà (I), $\imath \bar{a}(\mathrm{E})$ & & \\
\hline вара (Б) & àzá (I), ใā (E) & àzá (I), $2 \bar{a}(\mathrm{E})$ & & \\
\hline ср.-Юж. (Б) & àzá (I), ใā (E) & àzá (I), ใā (E) & & \\
\hline янгере (Б) & ใà (I), $2 \bar{a}(\mathrm{E})$ & ใà (I), $\{\bar{a}(\mathrm{E})$ & & \\
\hline моно (Б) & $e z e(\mathrm{I}), a(\mathrm{E})$ & $e z e(\mathrm{I}), a(\mathrm{E})$ & & \\
\hline моно-били (Б) & $\imath \grave{a}(\mathrm{I}), \imath \bar{a}(\mathrm{E})$ & àzá (I), $2 \bar{a}(\mathrm{E})$ & ใà / àzá (I), $2 \bar{a}(\mathrm{E})$ & $\grave{a} z a ́$ (I), $\bar{a} \imath \bar{a}(\mathrm{E})$ \\
\hline С3-кара (Г) & ใéć, Záá (apx.) & $y \varepsilon ́$ & $-y \varepsilon ́(\mathrm{INAL}), k \varepsilon^{\prime} \varepsilon$ (AL) & ใéć, ?áá (арх.) \\
\hline СЗ-лаи (Г) & $2 \varepsilon^{\prime}$ & $y \varepsilon ́$ & $-y \varepsilon ́$ (INAL), ké (AL) & $2 \varepsilon$ \\
\hline Ю3-були (Г) & $2 j$ & $2 j$ & -Zj́ (INAL), bj̀ (AL) & $2 j$ \\
\hline Ю3-тоонго (Г) & $2 j$ & $2 j$ & -Zj́ (INAL), bj̀ź (AL) & $2 j$ \\
\hline Ю3-биянда (Г) & $2 j$ & $2 j$ & -Zj́ (INAL), pj̀ßj (AL) & \\
\hline мбодомо (Г) & २ćlé & $2 s^{\prime}$ & $\begin{array}{l}\text {-\{ćlé (INAL), vèlé } \\
\text { (AL) }\end{array}$ & \\
\hline бокото $(Г)$ & $2 \varepsilon^{\prime}$ & $y \varepsilon ́, r \varepsilon ́$ & $\begin{array}{l}\text {-yé / -ré (INAL), kéré } \\
\text { / kéć (AL) }\end{array}$ & \\
\hline бозом $(\Gamma)$ & Zéré & ré (DO), háré (IO) & -ré (INAL), káré (AL) & \\
\hline босангоа $(\Gamma)$ & ใèrè (IPF), حદ́ré (PF) & ré (DO), héré (IO) & -ré (INAL), kérć (AL) & ใéré \\
\hline гбану (Г) & Zálé & lé (DO), hélé (IO) & $\begin{array}{l}\text { lé (INAL), kélé / dààlé } \\
\text { / ndèlé (AL) }\end{array}$ & \\
\hline али $(Г)$ & $\imath \bar{a} l \bar{\varepsilon}, \imath \bar{a}$ & $l \bar{\varepsilon}$ & $\begin{array}{l}l \bar{\varepsilon} \text { (INAL), kél} \bar{\varepsilon} / d \bar{a} l \bar{\varepsilon} \\
(\mathrm{AL})\end{array}$ & \\
\hline манза $(\Gamma)$ & $l \bar{\varepsilon}, y \bar{\varepsilon}$ & $l \bar{\varepsilon}(\mathrm{DO}), h \tilde{a} \mid \bar{\varepsilon}(\mathrm{IO})$ & $\begin{array}{l}l \bar{\varepsilon} \text { (INAL), kốl } \bar{\varepsilon} / d \bar{a} l \bar{\varepsilon} \\
(\mathrm{AL})\end{array}$ & \\
\hline нгбака $(\Gamma)$ & $l \bar{\varepsilon}$ & $l \bar{\varepsilon}(\mathrm{DO}), h \tilde{a} l \bar{\varepsilon}(\mathrm{IO})$ & $\begin{array}{l}l \bar{\varepsilon} \text { (INAL), dàl } \bar{\varepsilon} / \text { mól } \bar{\varepsilon} \\
/ \text { kốl } \bar{\varepsilon}(\mathrm{AL})\end{array}$ & \\
\hline бофи (Г) & $\imath \bar{\varepsilon} l \bar{\varepsilon}$ & $l \bar{\varepsilon}(\mathrm{DO}), h \bar{a} l \bar{\varepsilon}(\mathrm{IO})$ & $\begin{array}{l}n d \dot{l} l \bar{\varepsilon} \text { (INAL), kóndèle } \\
\text { (AL) }\end{array}$ & \\
\hline банганду (Г) & $2 j$ & 2j́ (DO), háró (IO) & mó & \\
\hline якома (Нд) & $\begin{array}{l}\text { hè / Zè, hé / Zé (FUT, } \\
\text { SUBJ) }\end{array}$ & & & hé \\
\hline гбайи (Нд) & $\begin{array}{l}\text { álénè / ánè (I), álémē } \\
\text { (E) }\end{array}$ & $\begin{array}{l}\text { álénè / ánè (I), álémē } \\
\text { (E) }\end{array}$ & $\begin{array}{l}\text {-lénè / -rínì (I), } \\
\text {-lémè / -rímì (E) }\end{array}$ & \\
\hline мунду (Нк) & $(\bar{a}) n \bar{\imath}$, kpárā & $\bar{a}, \imath \bar{a}, n \bar{\imath}$ & $\bar{a}, 2 \bar{a}, n \bar{\imath}$ & $\bar{a}, \imath \bar{a}, n \bar{\imath}$ \\
\hline нгбака-мабо (Нк) & 2āóò & & & \\
\hline монзомбо (Нк) & ?i” (DU), ná (I), $\imath \bar{a}(\mathrm{E})$ & & & \\
\hline гбанзири (Нк) & $y \bar{a}$ & & & \\
\hline бака (Нк) & $\begin{array}{l}2 \bar{a}(\mathrm{DU}), n i, \imath \bar{a} . . . n i ̀ \\
(г л .), \imath \bar{a} n \grave{i}(\text { негл.) (I), } \\
\eta \bar{a}(\mathrm{E})\end{array}$ & & & $\begin{array}{l}\text { yātínì, yāyātínì (I), } \\
\text { yāyāa (E) }\end{array}$ \\
\hline майого (Нк) & $-y \bar{a}$ & & & \\
\hline ндунга (M) & $n u ́$ & $n u ́(\mathrm{IO})$ & $n u ́$ & \\
\hline
\end{tabular}




\begin{tabular}{|c|c|c|c|c|}
\hline & субъект & объект & притяжат. & фоках. \\
\hline мба (M) & i & & $\bar{i}$ & \\
\hline донго-ко (М) & $n \grave{a}(\mathrm{I}), n \bar{\imath}(\mathrm{E})$ & & $n \grave{a}(\mathrm{I}), n \bar{\imath}(\mathrm{E})$ & \\
\hline ма (M) & Èpí & & & \\
\hline cepe $(\mathrm{C})$ & $d \bar{\imath}$ & & & \\
\hline баи (C) & $d \bar{u}$ & & & \\
\hline занде (3) & $\grave{a}(n \grave{\imath})$ & rànì & $\begin{array}{l}\text {-ránì (INAL), gàánì } \\
(\mathrm{AL})\end{array}$ & ànì \\
\hline барамбу (3) & 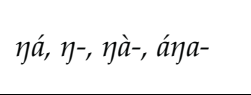 & -ya,-arà / -àrc̀ / -árà & $\begin{array}{l}\text {-éra / -árà / -crè / -ara } \\
\text { (INAL), gàrà (AL) }\end{array}$ & \\
\hline памбиа (3) & $a_{-}^{-},-\eta \hat{a}$ & $-\eta a$ & $\begin{array}{l}-\eta a /-\gamma a(\mathrm{INAL}), a w a a \\
(\mathrm{AL})\end{array}$ & \\
\hline геме (3) & $\begin{array}{l}\text { hàa }(\mathrm{DU}) \text {, hàán }(\mathrm{I}) \text {, } \\
\text { hàn }(\mathrm{E})\end{array}$ & & & \\
\hline нзакара (3) & $\grave{a}(n i)$ & & -àní & ànì \\
\hline
\end{tabular}

Как уже подчёркивалось выше, плюральные местоимения во многих убангийских языках характеризуются фонетической структурой VCV. Это явление характерно прежде всего для показателей субъекта, в то время как в объектных (т.е. большей частью суффиксальных) показателях первый вокалический элемент не присутствует, а структура, соответственно, упрощается до CV. Подобная схема наиболее ярко выражена в языках банда, гбая и занде, засвидетельствована в группе нгбака. Весьма вероятно, что первая гласная в двусложных формах является префиксом, характеризующим именно субъектное значение. Для языков убанги в целом весьма нехарактерны слова с вокалическим анлаутом, примеры такого рода существуют только в местоимениях и служебных частях речи, а также в связанных морфемах. Для устранения вокалического анлаута в целом ряде языков используется глоттальный приступ 2- (наиболее последовательно - в языках гбая) или придыхание $h$ - (например, в геме и якома), которые, таким образом, не подлежат сравнению с согласными элементами местоименных корней других языков.

Особенностью местоимений 1PL в убанги является уже указанное выше широкое распространение категории расширенного 1 лица. Данная категория представляется довольно древней: она может быть надёжно реконструирована для языков банда. Отдельные языки нгбанди, нгбака, мба и занде также обладают категорией расширенного 1 лица.

Так как наличие расширенных (эксклюзивных, инклюзивных, дуальных) местоимений создаёт широкое многообразие форм, целесообразно вычленить те из них, которые могут иметь праязыковое происхождение.

Наиболее обещающим в этой связи представляется сравнение инклюзивной формы

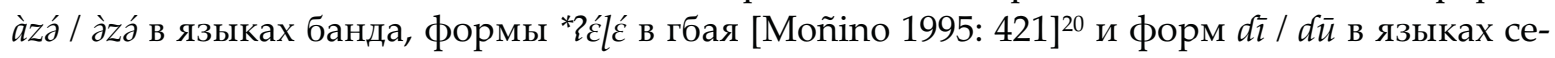
ре. Соответствие $t / l / d / d$, широко распространённое не только в убангийских языках, но и в целом в Западной и Центральной Африке, выглядит надёжным и имеет ряд подтверждений как в других группах языков семьи, так и в материалах для внешнего сравнения. Интервокальная спирантизация $d / d>z$ также типологически вполне обоснована. Кроме того, нужно отметить возможность взаимного конвергентного влияния между языками банда и соседними с ними языками центральносуданской семьи, ср. местоиме-

${ }^{20}$ В ряде языков банда происходит ослабление интервокальной латеральной фонемы ${ }^{*}>y$, в некото-

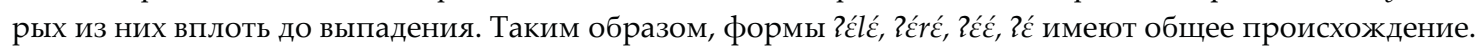


ния 1PL в тех из них, чьи ареалы географически примыкают к ареалам языков банда на обширной территории северной и северо-западной ЦАР:

$$
\begin{array}{ll}
\text { гула-сара } & z e ́(1 \mathrm{DU}) ; \\
\text { бубу } & z i(1 \mathrm{PL}) ; \\
\text { гула-зура } & z \bar{e}(1 \mathrm{PL} . \mathrm{E}), z \bar{e} g(1 \mathrm{PL} . \mathrm{I}) ; \\
\text { сара-каба } & j e ́, \text { jéje (1PL); } \\
\text { юлу } & j a ̈ \text { (1DU) [Boyeldieu 1987; Nougayrol 1999; Moser 2004]. }
\end{array}
$$

При том, что в целом парадигмы указанных языков и банда несводимы к общему генетическому источнику, взаимовлияние отдельных форм в составе этих парадигм вплоть до заимствования никогда нельзя исключать в условиях тесных языковых контактов, характерных для центральноафриканского региона. Важно помнить, что миграции носителей языков убанги, весьма возможно, проходили по районам расселения носителей центральносуданских языков, что не могло не наложить значительного субстратного отпечатка на структуру языка иммигрантов [Saxon 1982]. В рассматриваемом нами случае именно влияние центральносуданских языков могло стать причиной нетривиального фонетического перехода *d/ ${ }^{*} d>$ * $z$ уже в праязыке банда.

В языке бака (группа нгбака) фокализованное местоимение инклюзива үā-tínì может

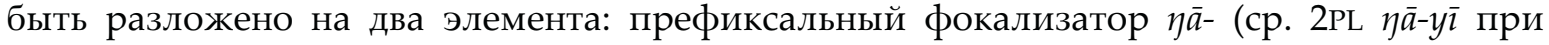
субъектном yī, 3PL $\eta$-ó при субъектном wó, объектном ó) и собственно личный показатель -tíni, сохранившийся в этом виде только в фокализованной серии.

Конечная гласная формы банда должна восходить к *-е [Boyd 1988: 75], эта же гласная сохраняется в западно-центральных диалектах (тех же, что сохраняют качество гласной и в других местоимениях парадигмы, см. выше). Кажется возможным, таким образом, восстановить в праязыковом местоимении гласную фонему *-е. В банда она подверглась редукции до уровня шва, но $\bar{\imath} /$ е ещё обнаруживаются в западно-центральных диалектах, лангбаше и моно. В гбая, напротив, происходит переход в более широкую - $\varepsilon$.

Что же касается внешних параллелей, то * $t I$ / *di восстанавливается, в частности, в качестве местоимения 1PL в языках гур, ${ }^{*} t i /{ }^{*} t u$ - для языков нескольких групп языков бенуэ-конголезской семьи, в том числе *tv- - для префиксального субъектного маркера в языках банту. Из атлантических языков местоимение * $t V$ демонстрируют языки биджого и, возможно, суа [Pozdniakov \& Segerer 2004: 152]. Впрочем, для убангийских языков приходится признать звонкий характер праязыковой согласной фонемы: как по совокупности рефлексов, так и, в особенности, по причине наличия фонемы ${ }^{*} z$ в языках банда, которую значительно логичнее возводить именно $\mathrm{k} * d$ * $d$, но не к $*$.

Вопреки внешнему фонетическому сходству, формы гбайи álénè (инклюзив) и álémē (эксклюзив) не восходят к рассматриваемой нами гипотетической праформе *dI (где I некоторая переднерядная гласная фонема). Элемент al- здесь лишь маркирует плюралис - в данном случае эксклюзивного местоимения от $m \bar{e}$ 'я'. Ту же морфему видим в 2PL alémj̀ (ср. mj̀ 'ты') и 3PL álà (ср. якома à 'он, она, оно (INAN)'). Плюральную морфему alможно сравнить с là- в местоимении 3РL ндунга là-mé, при 3SG mé.

Необъяснённым в формах гбайи остаётся лишь элемент -nѐ в составе инклюзивного местоимения. Впрочем, форма $n I$ также является распространённой среди местоимений 1PL целого ряда языков семьи. В частности, в языке бака видим инклюзивное местоимение $n \grave{\imath} /$ \{ānì, в занде и нзакара - местоимения 1PL ànì. Напротив, в донго-ко (группа мба) $n \bar{\imath}$ имеет эксклюзивное значение.

Другой распространённой моделью можно назвать па / ұa: ср. монзомбо па́ (инклюзив), бака үā (эксклюзив), донго-ко па̀ (инклюзив), барамбу и памбиа үá / үâ. 
Разброс значений указанных форм (инклюзивное, эксклюзивное или нейтральное), а также их ограниченное распространение в пределах каждой группы языков может означать лишь то, что на праязыковом уровне им невозможно приписать значения инклюзивности или эксклюзивности. Ни в одной из групп, кроме банда, чёткого противопоставления праформ обоих этих значений мы не видим. Весьма вероятно, таким образом, что на уровне праязыка убанги категория расширенного первого лица ещё не функционировала: она развилась лишь в общем предке языков банда, а также была воспринята в результате ареальных контактов отдельными языками других групп. И действительно, четыре из пяти языков нашей подборки, находящихся вне группы банда и обладающих этой грамматической категорией (гбайи, монзомбо, донго-ко и геме) соседствуют с ареалом языка (нередко более крупного), также имеющего категорию клюзивности: для гбайи это банда, для монзомбо - мбанджа, для донго-ко - различные центральносуданские языки, для геме - родственный язык нделе и центральносуданский язык лутос. Область языка бака в Камеруне и Габоне соприкасается с зонами распространения бантоидных языков с развитым дуалисом - макаа и коонзиме.

Рассмотрим ряд других типов личных местоимений 1PL в убангийских языках. В группе банда восстанавливается эксклюзивное местоимение * $2 \bar{a}$. Однако краткость этой формы не позволяет выводить надёжные сравнения с формами других убангийских языков в частности, формами языков занде $\grave{a}$. Что касается глоттального элемента в местоимениях группы гбая, то здесь, как можно видеть, он имеет чисто фонетическую функцию, устраняя вокалический анлаут. Такие примеры, как Ю3 банда 2j, якома hè / Zè, мба $i$, не позволяют надёжно определить их происхождение, но, судя по недостаточному распространению, могут являться инновациями. Среди очевидных новообразований - также местоимения мунду kpárā (субъект) и ма غ̇рí (с плюральным элементом - $p V$, cp. 2PL òpú, 3PL ìpò).

В итоге единственной формой, претендующей на праязыковое происхождение по материалу сразу нескольких групп убангийских языков, остаётся *(V)de / * $(V) d i$. Реконструкции некоторых промежуточных праформ приведены в нижеследующей Таблице 8.

\begin{tabular}{l|l}
\hline банда & *(à)zé, *zé (I), *?ā (E) \\
\hline гбая & *(2é) lé \\
\hline нгбака & *na / ni \\
\hline мба & *na / ni ? \\
\hline сере & *dî \\
\hline занде & *à(nì) \\
\hline убанги & *(V)de / (V)di \\
\hline
\end{tabular}

Таблицุа 8

\section{2-е дицо множественного числа}

Таблиияа 9

\begin{tabular}{l|l|l|l|l}
\hline & субъект & объект & притяжат. & фоках. \\
\hline ЗЦ-дакпа (Б) & $\imath \bar{e}$, ye, $e$ & $e$ & yá & éyá, èryá \\
\hline ЗЦ-уоджо (Б) & $n \bar{e}$ & $n \bar{e}$ & & \\
\hline лангбаше (Б) & $\imath \bar{e}$, ye, $e$ & $\imath \bar{e}$ & & \\
\hline
\end{tabular}




\begin{tabular}{|c|c|c|c|c|}
\hline & субъект & объект & притяжат. & фокал. \\
\hline бамбари (Б) & $y \bar{e}$ & $2 \bar{e}$ & $2 \bar{e}$ & $2 \bar{e} ? \bar{e}$ \\
\hline мбанджа-мбанза (Б) & ànzá & ànzá & & \\
\hline ЮЦ-нгбугу (Б) & $n \bar{e}$ & $\eta \bar{e}$ & $\eta \bar{e}$ & nēné \\
\hline нделе (Б) & $y \bar{e}$ & $y \bar{e}$ & & \\
\hline вара (Б) & $2 \bar{e}$ & $2 \bar{e}$ & & \\
\hline янгере (Б) & $2 \bar{\imath}$ & $2 \bar{\imath}$ & & \\
\hline моно (Б) & ye,e & $e$ & & \\
\hline моно-били (Б) & $2 \bar{e}$ & $2 \bar{e}$ & $\bar{e} ? \bar{e}$ & $2 \bar{e}$ \\
\hline С3-кара $(Г)$ & Z⿱一́n & $n \varepsilon ́$ & -né (INAL), kénć (AL) & ใéné \\
\hline С3-лаи (Г) & ใénć & $n \varepsilon ́$ & 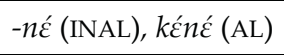 & ใéné \\
\hline Ю3-були (Г) & ใéné & ใéné & $\begin{array}{l}\text { - }\{\varepsilon ́ n \varepsilon ́ \text { (INAL), bèné } \\
(\mathrm{AL})\end{array}$ & ใénć \\
\hline Ю3-тоонго (Г) & ใénć & Zéné & $\begin{array}{l}-\{\varepsilon ́ n \varepsilon ́(\mathrm{INAL}), \text { bèné } \\
(\mathrm{AL})\end{array}$ & ใÉné \\
\hline Ю3-биянда (Г) & ใéné & ใénć & 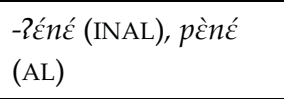 & \\
\hline мбодомо (Г) & ใéné & ใéné & $\begin{array}{l}-2 \varepsilon ́ n \varepsilon ́ \text { (INAL), vèné } \\
(\mathrm{AL})\end{array}$ & \\
\hline бокото $(\Gamma)$ & ใéné, ใóndó & $n \varepsilon ́$ & né (INAL), kénć (AL) & \\
\hline бозом $(Г)$ & yó?ó, yó & yó?ó (DO), háyó (IO) & $\begin{array}{l}\text {-yó zó (INAL), kóyó } \\
\text { (AL) }\end{array}$ & \\
\hline босангоа $(\Gamma)$ & wì (IPF), wí (PF) & wí (DO), háwí (IO) & $\begin{array}{l}-w i ́ \text { / -í (INAL), kóí } \\
(\mathrm{AL})\end{array}$ & $w i ́$ \\
\hline гбану (Г) & ใéné & né (DO), héné (IO) & $\begin{array}{l}n \varepsilon ́(\mathrm{INAL}), k \varepsilon ́ n \varepsilon ́ \text { / } \\
\text { dààné / nèné (AL) }\end{array}$ & \\
\hline али $(Г)$ & $\{\bar{\varepsilon} n \bar{\varepsilon}$ & $n \bar{\varepsilon}(\mathrm{DO}), \mathscr{\emptyset}^{\prime} n \bar{\varepsilon}(\mathrm{IO})$ & $\begin{array}{l}n \bar{\varepsilon}(\mathrm{INAL}), k \operatorname{c}^{\prime} \overline{\bar{\varepsilon}} / \\
\operatorname{dā} n \bar{\varepsilon}(\mathrm{AL})\end{array}$ & \\
\hline манза $(\Gamma)$ & $n \bar{\varepsilon}$ & $n \bar{\varepsilon}(\mathrm{DO}), h \tilde{a} n \bar{\varepsilon}(\mathrm{IO})$ & 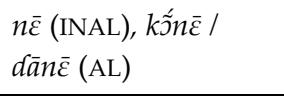 & \\
\hline нгбака $(\Gamma)$ & $n \bar{\varepsilon}$ & $n \bar{\varepsilon}(\mathrm{DO}), h \tilde{a} n \bar{\varepsilon}(\mathrm{IO})$ & 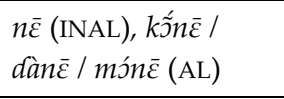 & \\
\hline бофи (Г) & $2 \bar{\varepsilon} n \bar{\varepsilon}$ & $n \bar{\varepsilon}(\mathrm{DO}), h \bar{a} n \bar{\varepsilon}(\mathrm{IO})$ & $\begin{array}{l}n \dot{n} n \bar{\varepsilon} \text { (INAL), kónèn } \bar{\varepsilon} \\
(\mathrm{AL})\end{array}$ & \\
\hline банганду (Г) & 2Éné & ใénć (DO), hà?éné (IO) & móné & \\
\hline якома (Нд) & $h \tilde{\imath}, h \tilde{\imath}$ & & & $h \tilde{\imath}$ \\
\hline гбайи (Нд) & álémò & álémò & $\begin{array}{l}\text {-lémj̀ (INAL), -rímj̀ } \\
(\mathrm{AL})\end{array}$ & \\
\hline мунду (Нк) & $y \bar{\imath}$ & $y \bar{\imath}$ & $y \bar{\imath}$ & $y \bar{\imath}$ \\
\hline нгбака-мабо (Нк) & $2 \bar{\imath}$ & & & \\
\hline монзомбо (Нк) & $2 \bar{\imath}$ & & & \\
\hline гбанзири (Нк) & $y \bar{\imath}$ & & & \\
\hline бака (Нк) & $y \bar{\imath}, 2 \bar{\imath}$ & $\eta \bar{\imath}$ & & $\eta \bar{a} y \bar{\imath}$ \\
\hline майого (Нк) & $-y \bar{\imath}$ & & & \\
\hline
\end{tabular}




\begin{tabular}{|c|c|c|c|c|}
\hline & субъект & объект & притяжат. & фокал. \\
\hline ндунга (M) & ná & & & \\
\hline мба (М) & ná & & na & \\
\hline донго-ко (М) & $d a ̀$ & & dà & \\
\hline ма (M) & òpú & & & \\
\hline cepe $(\mathrm{C})$ & $r \bar{\varepsilon}$ & & & \\
\hline баи (C) & $d \bar{a}$ & & & \\
\hline занде (3) & ànì, ò(nì)- & rànì & $\begin{array}{l}\text {-rónì (INAL), gòónì } \\
\text { (AL) }\end{array}$ & ònì \\
\hline барамбу (3) & 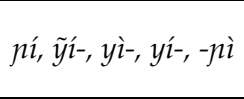 & $\begin{array}{l}\text {-ni / -yi (DO), ìrì / irì } \\
\text { / érì (IO) }\end{array}$ & $\begin{array}{l}\text {-íri / -ćrì / erì / -ri } \\
\text { (INAL), gyìrì (AL) }\end{array}$ & \\
\hline памбиа (3) & $i-,-n i,-n i$ & $-n i$ & $\begin{array}{l}\text {-li / } \eta i(\mathrm{INAL}), \varepsilon j i \text { / } \\
\text { elyi (AL) }\end{array}$ & \\
\hline геме (3) & hغ̀nદ̀ & & & \\
\hline нзакара (3) & RÉnغ̀, ónt-, ònì & & -òní & òni, ènè \\
\hline
\end{tabular}

В отсутствие дополнительной оппозиции между двойственными, эксклюзивными и инклюзивными формами, существенно расширяющей набор форм несингулярных местоимений 1 л., формы 2PL в убангийских языках демонстрируют более высокую степень однородности.

Одной из моделей, подлежащей сравнению и распространённой сразу в нескольких группах языков семьи, является модель (V)nI / nI, содержащая гласную фонему передних рядов: $i, l, e$ или $\varepsilon$. Формы, объединяемые данной моделью, распространены в языках банда, гбая и занде, и во всех трёх есть возможность вполне надёжно реконструировать их в качестве праформ на групповом уровне. В группе банда западно- и южно-

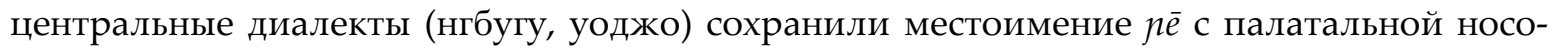
вой согласной, в то время как в других языках группы она была ослаблена: $n>y$ (лангбаше, нгао) > ноль согласной (ЗЦ-дакпа, моно), с последующим добавлением эвфонической глоттальной смычки 2-, характерной и для других местоимений парадигмы с вокалическим анлаутом (см. выше). В языке янгере происходит сужение $\bar{e}>\bar{\imath}$. Среди диалектов банда, данные которых имеются в нашем распоряжении, только мбанджа-мбанза демонстрирует нетипичное местоимение ànzá, имеющее инновационное происхождение.

Диалекты группы занде показывают тот же разброс вариантов начальной согласной: в барамбу мы видим варианты местоимения лі / nì, с последующей спирантизацией уіi, затем с исчезновением назализации уí / yì. В памбиа диалектные формы варьируют между пі и $i$. Характерная для плюральных местоимений вокалическая префиксация отмечается в занде д̀nі̀, геме hغ̀nغे и дилаектных вариантах нзакара ใغ́nغ̀ / ènè / ònì.

Данные языков гбая дают все основания поддержать гипотезу И. Моньино [Моñino

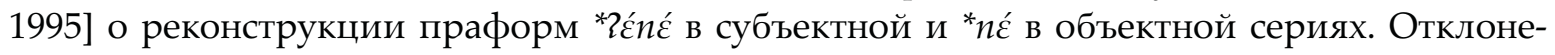
ния от рефлексов этих праформ минимальны: форма языка гбая-босангоа wì / wí выглядит явным новообразованием, созданным под влиянием соседней формы парадигмы: местоимения 3PL wà / wá. Весьма вероятно, что и формы языка бозом 2PL yó 亿́́ и 3PL wó 亿ò стали результатами аналогического выравнивания.

Существует реальная возможность сравнить перечисленные данные с местоимениями языков нгбака, восходящими к праформе * уї. Здесь ослабление начальной носовой до глайда, по-видимому, произошло уже на уровне праязыка группы, ср. дальнейшую её 
мутацию до глоттального приступа, к примеру, в монзомбо и бака. С этими же формами может быть сопоставлено местоимение 2PL языка якома (группа нгбанди) hĩ, назализованная гласная которого служит свидетельством утраченного носового согласного звука.

По всей видимости, нет оснований с такой же вероятностью постулировать генетическое родство форм *nI / *nI с ná / ná / dà, которые характеризуют группу языков мба. Эти последние, впрочем, легко сравнить с $d \bar{a}$ в языке баи (группа сере). Гипотетической общей праформой этих местоимений может быть па, так как развитие *na > na / da типологически более оправданно и распространено, нежели обратное. А раз так, то происхождение $п а$ из *ni-a также не выглядит невероятным, что уже позволяет сблизить формы групп мба и сере с праформой, рефлексы которой обсуждались выше.

Внешнее сравнение позволяет подтвердить реконструкцию. В языках бенуэ-конго реконструируется показатель 2PL *ne / *ni, в гур - *nI, в ква - *ne, схожие формы отмечены в атлантических языках.

В завершение обзора можно указать и ещё одну несомненную инновацию: форму гбайи àlémò, созданную, как это уже кратко упоминалось нами, соединением плюрального маркера àlé- и местоимения 2SG mว̀.

Таким образом, мы реконструируем нижеследующие (Таблица 10) праязыковые местоимения для групп языков убанги и собственно праязыка семьи.

\begin{tabular}{|c|c|}
\hline банди & ${ }^{*}$ nē \\
\hline гбая & *(?ć)né \\
\hline нгбанди & якома $h \tilde{\imath}<* \mathbf{N i}$ \\
\hline нгбака & ${ }^{*} \mathbf{y} \overline{\mathbf{1}}$ \\
\hline cepe & * dā ? \\
\hline занде & $*(V)$ nì \\
\hline убанги & $*(\varepsilon)$ ne $/{ }^{*}(\varepsilon)$ ni \\
\hline
\end{tabular}

Таблицุа 10

\section{5. Местоимения 3 дица}

Выше уже упоминалось об особенностях личных местоимений третьего лица. Беглого взгляда на сводную таблицу, содержащую данные по нескольким десяткам языков семьи, вполне достаточно, чтобы увидеть, что восстановление праязыковых форм возможно не выше, чем на уровне отдельных подгрупп, но часто и этот уровень недоступен для реконструкции из-за широкого разброса вариантов, несводимых к единому предку.

Данная ситуация объясняется относительно поздним происхождением местоимений 3 лица по сравнению с их соседями по парадигме, что вполне нормально с точки зрения типологии языков мира (ср., например, обзорные монографии [Helmbrecht 2004] или [Bhat 2005]). Какими бы ни были источники их происхождения, процесс смены показателей 3 лица в языке проходит более интенсивно, чем показателей двух первых лиц.

Схожая ситуация сегодня наблюдается в ряде языков нигер-конго, с той разницей, что источником происхождения показателей 3 лица выступают не демонстративы, а чаще именные классные аффиксы. В частности, в языках семей бенуэ-конго, ква, гур показатели именных классов играют роль личных глагольных показателей 3 лица. В убангийских языках личные показатели 3 лица являются составными элементами место- 
именных парадигм, поэтому мы должны рассмотреть их формы более подробно и попытаться охарактеризовать их происхождение там, где это возможно.

Местоимения третьего лица в убангийских языках отличны от других местоимений парадигмы ещё и тем, что обладают особыми грамматическими категориями: рода, личности и одушевлённости. В некоторых языках эти категории распространены только на формы единственного числа. Наиболее распространена оппозиция форм для обозначения одушевлённых - неодушевлённых референтов (в языках банда, гбая, нгбанди, мба). В языках мба и занде в сингулярисе проводится различие местоимений для обозначений мужчин и женщин - категория рода является крайне нехарактерной чертой для нигеро-конголезских языков. Наконец, в ряде языков занде существуют особые формы показателей 3SG для обозначения животных, то есть противопоставляются четыре формы по категориям рода, одушевлённости и личности: ср. занде kó (лица м. p.), rí (лица ж. р.), (h)̀े / (h)ì (животные), sí / tí (неодушевлённые предметы). При отсутствии в занде именных классов система личных местоимений 3 лица может рассматриваться как один из возможных её рудиментов, наравне с другими следами именной классификации [Tucker 1959: 117-121], тем более что именно в занде отчётливо видно, что личные показатели 3 лица не обладают генетическим родством с указательными местоимениями.

Несубъектные местоимения 3 лица так же, как и местоимения других лиц, обладают категориями отчуждаемой - неотчуждаемой принадлежности.

Таблициа 11

\begin{tabular}{|c|c|c|c|c|}
\hline & субъект & объект & притяжат. & фокализ. \\
\hline мбрес-бука (Б) & $c \grave{~}$ & $c \grave{c}$ & & \\
\hline мбрес-мбере (Б) & sè & sè & & \\
\hline мбрес-сабанга (Б) & šè & šè & & \\
\hline ЗЦ-дакпа (Б) & $c a, c \bar{e}(\mathrm{AN}), \grave{a}(\mathrm{INAN})$ & $c \bar{a}$ & $c \bar{a}$ & $\grave{e} c \bar{a}$ \\
\hline ЗЦ-гби (Б) & šè & š̀ & & \\
\hline ЗЦ-гбага (Б) & $c \grave{e}$ & $c \grave{e}$ & & \\
\hline банда-гбага (Б) & šè & šè & & \\
\hline банда-хай (Б) & $c \grave{e}$ & $c \grave{e}$ & & \\
\hline ЮЦ (Б) & $c \grave{e}(\mathrm{AN}), \bar{a}(\mathrm{INAN})$ & $c \grave{e}(\mathrm{AN})$ & yé / nā (AN) & cècēe (AN) \\
\hline лангбаше (Б) & $c \grave{e}$ & $c \grave{e}$ & & \\
\hline бамбари (Б) & $c e ̀(\mathrm{AN}), a ́$ (INAN) & $\begin{array}{l}\text { cè (AN), nà / tánà } \\
\text { (INAN) }\end{array}$ & nà & tánà \\
\hline мбанджа (Б) & $\mathrm{ca}$ & $c a$ & & \\
\hline нделе (Б) & sà & sà & & \\
\hline вара (Б) & cà & cà & & \\
\hline ср.-юж. (Б) & $c \grave{e}$ & $c \grave{e}$ & & \\
\hline янгере (Б) & $c \grave{~}$ & $c \grave{e}$ & & \\
\hline моно (Б) & $\begin{array}{l}\text { čà (AN), à / átánà } \\
\text { (INAN) }\end{array}$ & $\begin{array}{l}\text { šè (AN), nà / tánà } \\
\text { (INAN) }\end{array}$ & $j \bar{e}(\mathrm{AN}), n \grave{a}(\mathrm{INAN})$ & èšè (AN) \\
\hline С3-кара $(\Gamma)$ & $2 \grave{a}, 2 \tilde{a}$ & $-\grave{\tilde{a}},-\grave{a}$ & $-\grave{a} /-a ̀$ (INAL), kJ̃́à (AL) & $2 \grave{a}, 2 \tilde{a}$ \\
\hline С3-лаи (Г) & $2 \grave{a}$ & ใà & -ใà (INAL), kóà (AL) & 2à \\
\hline Ю3-були (Г) & $\begin{array}{l}\text { ¿à / wènc̀ (AN), yò } \\
\text { (INAN) }\end{array}$ & wÈnغ̀ (AN), yò (INAN) & $\begin{array}{l}\text {-à (од. но.), pèáà } \\
\text { (од. о.) }\end{array}$ & $\begin{array}{l}\text { 2à / wènc̀ (AN), yò } \\
\text { (INAN) }\end{array}$ \\
\hline
\end{tabular}




\begin{tabular}{|c|c|c|c|c|}
\hline & субъект & объект & притяжат. & фокадиз. \\
\hline Ю3-тоонго (Г) & 2à & 2à & -?à (INAL), bjáà (AL) & 2à \\
\hline Ю3-биянда (Г) & 2à, wèn & wèn & $-\grave{a}(\mathrm{INAL}), p \check{\varepsilon} a ̀$ (AL) & \\
\hline мбодомо (Г) & ใà / à (TOP), wغ̀nغ̀ & wèn & -nè (INAL), wáà (AL) & ใà / à (TOP) \\
\hline бокото $(\Gamma)$ & $2 \grave{a ̀ ~}$ & $2 \grave{a ̀ ~}$ & $-\grave{\tilde{a}}(\mathrm{INAL}), k \tilde{\tilde{\partial} a ̀ ~}(\mathrm{AL})$ & \\
\hline бозом $(\Gamma)$ & $2 \tilde{a}, m a ́$ & ใã̀ (DO), hấa & - $2 \grave{a}(\mathrm{INAL}), k \tilde{a} a \grave{a}(\mathrm{AL})$ & \\
\hline босангоа $(\Gamma)$ & $2 \grave{a ̀ ~}$ & ใà̃ (DO), hấa à (IO) & $-\grave{a}$ (INAL), kấà (AL) & 2 2à \\
\hline гбану (Г) & $2 \grave{a}$ & $-\grave{a}(\mathrm{DO}), h \tilde{a} a \grave{a}(\mathrm{IO})$ & 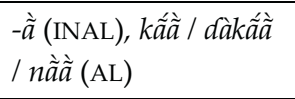 & \\
\hline али $(Г)$ & yà & yà & $\begin{array}{l}\text { yà (INAL), kíyà / dāà } \\
\text { (AL) }\end{array}$ & \\
\hline манза $(\Gamma)$ & $\imath \grave{a}(\mathrm{AN}), m a \hat{a}(\mathrm{INAN})$ & $\begin{array}{l}\text {-à (AN) / mâ (INAN), } \\
\text { háa â (IO) }\end{array}$ & $\begin{array}{l}-\grave{a}(\mathrm{AN}) / \text { mâ (INAN) } \\
\text { (INAL), kJ̃́ầ / dāà (AL) }\end{array}$ & \\
\hline нгбака (Г) & ?à (AN), má (INAN) & $\begin{array}{l}\text {-à (AN) / má (INAN), } \\
\text { hấa } \\
\text { (IO) }\end{array}$ & $\begin{array}{l}\text {-à (AN) / má (INAN) } \\
\text { (INAL), móà / kõãa / } \\
\text { dāà (AL) }\end{array}$ & \\
\hline бофи (Г) & wغ̀n & -à (DO), hà (IO) & jà (INAL), kójà (AL) & \\
\hline банганду (Г) & $\emptyset$ & zà (DO), házà (IO) & wà & \\
\hline якома (Нд) & $\begin{array}{l}\text { lò (AN), ló (од. FUT), } \\
\grave{a} / \text { á (INAN) }\end{array}$ & & & $l o ̀(\mathrm{AN}), \tilde{y} i$ (INAN) \\
\hline гбайи (Нд) & $w \bar{o}(\mathrm{AN})$ & $w \bar{o}(\mathrm{AN})$ & $-\grave{\varnothing}(\mathrm{INAL}),-r \grave{-}-\varnothing(\mathrm{AL})$ & \\
\hline мунду (Нк) & $\emptyset, a ́ a ̄, a ́, ~ Z a ́, ~ c ́, j$ & $n \bar{\varepsilon}, n \bar{a}, \bar{a}, d \bar{\imath}$ & $n \bar{\varepsilon}, n \bar{a}, \bar{a}, d \bar{\imath}$ & $\left(\dot{\varepsilon}^{\prime}\right) y \bar{\varepsilon}$ \\
\hline нгбака-мабо (Нк) & Zé & & & \\
\hline монзомбо (Нк) & ใë, ใÉ, ใä & & & \\
\hline гбанзири (Нк) & 2á, $\bar{a}$, yé & & & \\
\hline бака (Нк) & Zé & & & 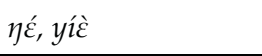 \\
\hline майого (Нк) & $-n \grave{u}$ & & & \\
\hline ндунга (M) & $m \varepsilon, m \varepsilon ́$ & $m \varepsilon$ & & \\
\hline мба (M) & ndè (М), bí (ж., жив.) & & $-e$ & \\
\hline донго-ко (М) & $\begin{array}{l}z a / z e ́(\mathrm{AN}), \text { wé } \\
\text { (INAN) }\end{array}$ & $\begin{array}{l}z a / z e ́(\mathrm{AN}), \text { wé } \\
\text { (INAN) }\end{array}$ & $\begin{array}{l}z a / z e ́(\mathrm{AN}), \text { wé } \\
\text { (INAN) }\end{array}$ & \\
\hline ма (M) & $\begin{array}{l}k j(\mathrm{M}), j(\mathrm{~F}), n d \varepsilon^{\prime} \\
\text { (INAN) }\end{array}$ & & & \\
\hline cepe $(C)$ & ní & & & \\
\hline баи (C) & $n i ́$ & & & \\
\hline занде (3) & $\begin{array}{l}k o ́-/ k \bar{o}(\mathrm{M}), r i ́-/ r \bar{\imath} \\
(\mathrm{F}), \dot{v}(\mathrm{AN})\end{array}$ & $\begin{array}{l}-k o ̀(\mathrm{M}),-r i \text { (ғ), -rì } \\
\text { (Жив.), -hè / -hà / ní } \\
\text { (INAN) }\end{array}$ & $\begin{array}{l}\text {-yò (лич.), -rami / ì } \\
\text { (жив.) (INAL); gàkò / } \\
\text { gâri /gāú (AL) }\end{array}$ & $\begin{array}{l}\text { kó (М), rí (ғ), (h)ì / } \\
\text { (h)ù (жив.), sí / tí } \\
\text { (INAN) }\end{array}$ \\
\hline барамбу (3) & kú (M), né (F) & $-k o ̀(\mathrm{M})$ & & \\
\hline памбиа (3) & ko (M), ne (F) & & $\begin{array}{l}-k o(\mathrm{M}),-n e(\mathrm{~F}),-m b a \\
(\text { жив.) }\end{array}$ & $\begin{array}{l}\text { águne (лич.), mba } \\
\text { (жив.) }\end{array}$ \\
\hline геме (3) & kō (M), àlé (F) & & & \\
\hline нзакара (3) & kó-, kj̀ & -kó (AN), -sé (INAN) & $-a \hat{k} o$ & $\begin{array}{l}\text { kó (лич.), ò (жив.), } \\
\text { si / ti (INAN) }\end{array}$ \\
\hline
\end{tabular}


В языках банда прослеживается единая праформа местоимений 3SG, которую уместно обозначить как ${ }^{*}$ ѐ, с некоторой исходной щелевой фонемой, реализуемой в различных языках как [t], [f] или [s]. Хорошо видно, что исходное значение этой формы одушевлённость: в тех языках, где функционирует категория одушевлённости, с её помощью обозначаются лица и животные. Напрашивается сравнение данной формы с местоимением донго-ко (группа мба) za / zé, также используемым для обозначения одушевлённых референтов.

Неодушевлённые предметы в банда маркируются формами, происходящими из *a. Это последнее, возможно, соответствует *a в языке якома. В языках гбая местоимение *2à (по мнению И. Моньино [Моñino 1995], с изначальной назализацией гласного, т.е. *2ầ), которое можно формально сравнить с указанным *a в банда и якома (с добавлением глоттальной смычки, устраняющей вокалический анлаут), напротив, обозначает одушевлённых референтов, в то время как для неодушевлённых предметов используются местоимения уо̀ (юго-западные диалекты), та́ (манза и нгбака).

В языках гбая присутствует ещё одна распространённая форма одушевлённого местоимения: *wغ̀nغ̀. Её грамматические отличия от *2а̃ указывают, по всей видимости, на объектное употребление (ср. противопоставление в западно-центральных диалектах и мбодомо). Однако в бофи эта форма полностью вытеснила субъектное местоимение, в мбодомо употребляется в качестве немаркированного субъектного показателя, в то время как *2а̃̀ имеет топикализованный оттенок.

Вокалические показатели характерны также для языков группы нгбака, где можно реконструировать формы *2é / 2á с высоким тоном. Глоттальная фонема здесь происходит из более раннего * $y$-, сохраняющегося в гбанзири, а также в фокализованных местоимениях мунду и бака.

Пегко восстанавливаются по крайней мере две формы местоимений 3sG для языков занде: это *ko для лиц мужского пола и, по всей вероятности, *ne / *ni для лиц женского пола - к этой форме могут восходить rí / rī в занде и à-lé в геме. Единственная параллель к одной из этих форм - местоимение мужского рода kj́ в мба. Она, впрочем, может являться и заимствованием, исходя из возможности миграции носителей мба на юг из северной ДР Конго, где они неизбежно должны были контактировать с языками занде.

В итоге мы можем реконструировать несколько праформ на уровне групп языков (Таблица 12), однако восстановить местоимение 3SG убангийского праязыка по имеющимся данным не в состоянии.

\begin{tabular}{l|l}
\hline банда & ${ }^{*}$ Cè / *Cà (AN), *a (INAN) \\
\hline гбая & *2à / là̀, *wènè (AN) \\
\hline нгбака & * 'é / *3á \\
\hline сере & ${ }^{*}$ ní \\
\hline занде & *kó (M), *né / *ní (F) \\
\hline
\end{tabular}

Таблицุа 12

В формах 3РL (Таблица 13) также наблюдается значительное расхождение лексем по группам языков, несмотря на то, что на уровне групп (т.е., по-видимому, на уровне около 1000 - 2000 лет назад) праформы восстанавливаются подчас довольно легко. 


\begin{tabular}{|c|c|c|c|c|}
\hline & субъект & объект & притяжат. & фокализ. \\
\hline мбрес (Б) & ànjēe & ànjēe & & \\
\hline мбрес-сабанга (Б) & ànjēe & ànjēe & & \\
\hline ЗЦ (Б) & ànjē & $\grave{a ̀ n j e \bar{e}}$ & njá & $\grave{a ̀ n j e \bar{e}}$ \\
\hline банда (Б) & ànjē & ànjē & & \\
\hline ЮЦ (Б) & ànjé, ànjēe & ànjé & ànjé, ànjē & ànjēnjé \\
\hline лангбаше (Б) & ànjē & $\grave{a ̀ n j e \bar{e}}$ & & \\
\hline бамбари (Б) & ànjē & ànjē & $-\grave{ø} n j \bar{e}$ & ànjēe \\
\hline мбанджа (Б) & ànjá & ànjá & & \\
\hline нделе (Б) & $\grave{a ̀ n j e \bar{e}}$ & ànje & & \\
\hline вара (Б) & ànjē & ànjē & & \\
\hline ср.-юж. (Б) & ànjē & ànjē & & \\
\hline янгере (Б) & ènjē & $\grave{e ̀ n j e}$ & ènjē & ènjē \\
\hline C3 $(\Gamma)$ & $w \grave{a}$ & $w \grave{a}$ & -wà (INAL), kówà (AL) & wà \\
\hline Ю3-були (Г) & mbúà & mbúà & $\begin{array}{l}\text {-mbúà (INAL), } \\
\text { pèmbúà (AL) }\end{array}$ & \\
\hline Ю3-биянда (Г) & mbúà & mbúà & $\begin{array}{l}\text {-mbúà (INAL), } \\
\text { pòmbúà (AL) }\end{array}$ & \\
\hline Ю3-тоонго $(Г)$ & wà & $w a ̀$ & $\begin{array}{l}\text {-wà (INAL), bùwáà } \\
(\mathrm{AL})\end{array}$ & $w a ̀$ \\
\hline мбодомо (Г) & wà & $w \grave{a}, w \hat{a}$ & $\begin{array}{l}\text {-wà / -wá (INAL), } \\
\text { mówà / mùà (AL) }\end{array}$ & \\
\hline бокото $(Г)$ & wò & wò & wò (INAL), kówò (AL) & \\
\hline бозом $(\Gamma)$ & wólò, mbó & wó?ò (DO), há?ò (IO) & -\{ò (INAL), kó?ò (AL) & \\
\hline босангоа $(\Gamma)$ & wà (IPF), wá (PF) & wà (DO), háwà (IO) & -\{ò (INAL), kówà (AL) & wà \\
\hline гбану $(Г)$ & $w \grave{~}$ & wj̀ (DO), hówj̀ (IO) & $\begin{array}{l}\text { wj̀ (INAL), kówj̀ / } \\
\text { dâáwò / ndòwj̀ (AL) }\end{array}$ & \\
\hline али $(Г)$ & wà & wà & $\begin{array}{l}\text { wà (INAL), kówà / } \\
\text { dāwà (AL) }\end{array}$ & \\
\hline манза $(\Gamma)$ & wà & wà (DO), hấwà (IO) & $\begin{array}{l}\text { wà (INAL), kốwà / } \\
\text { dāwà (AL) }\end{array}$ & \\
\hline нгбака $(\Gamma)$ & wà & wà (DO), hấwà (IO) & $\begin{array}{l}\text { wà (INAL), kốwà / } \\
\text { dāwà / mówà (AL) }\end{array}$ & \\
\hline бофи (Г) & yà & yà (DO), hāyá (IO) & ndìyá, kóndìyá (AL) & \\
\hline банганду (Г) & yówà̀ & $\begin{array}{l}\text { yówà (DO), háyówà } \\
\text { (IO) }\end{array}$ & yówà & \\
\hline якома (Нд) & Zálà, álà & & & álà \\
\hline гбайи (Нд) & álà & álà & $\begin{array}{l}\text {-álà (INAL), -r(i)álà } \\
\text { (AL) }\end{array}$ & \\
\hline мунду (Нк) & $\emptyset, w o ́, c ́, j$ & $\left(\varepsilon^{\prime}\right) w \bar{o}, \bar{u}$ & $\left(\varepsilon^{\prime}\right) w \bar{o}, \bar{u}$ & \\
\hline нгбака-мабо (Нк) & 2ó & & & \\
\hline монзомбо (Нк) & wö, ő & & & \\
\hline
\end{tabular}




\begin{tabular}{|c|c|c|c|c|}
\hline & субъект & объект & притяжат. & фокализ. \\
\hline гбанзири (Нк) & wó & & & \\
\hline бака (Нк) & wó & $-o ́$ & & yó \\
\hline майого (Нк) & -húò & & & \\
\hline ндунга (M) & làmé & & làmé & \\
\hline мба (M) & $b \varepsilon, b \varepsilon$ & & & \\
\hline донго-ко (M) & $z u ̀$ (AN), yé (INAN) & $z \grave{u}(\mathrm{AN}), y e ́(\mathrm{INAN})$ & $z \grave{u}(\mathrm{AN}), y e ́(\mathrm{INAN})$ & \\
\hline ма $(\mathrm{M})$ & ípò (AN), ndíró (INAN) & & & \\
\hline cepe $(C)$ & $n d i$ & & & \\
\hline баи (C) & ndí & & & \\
\hline занде (3) & $\begin{array}{l}\text { ((ò)- / yô (лич.), àmí } \\
\text { (жив.), sí (INAN) }\end{array}$ & $\begin{array}{l}\text { (y)ià, -yò (лич.), -rà } \\
\text { (жив.), é (INAN) }\end{array}$ & $\begin{array}{l}\text {-yò (лич. но.), -rami } \\
\text { (жив. но.), gâyò / } \\
\text { gáamí (AL) }\end{array}$ & $\begin{array}{l}\text { iı, íò, yô (лич.), àmí } \\
\text { (Жив.), sí / tí (INAN) }\end{array}$ \\
\hline барамбу (3) & $\begin{array}{l}\text { áká (лич.), ámbá } \\
\text { (жив.) }\end{array}$ & -akà (лич.) & $\begin{array}{l}\text {-ákà / -ako (лич.), } \\
\text {-ámbà / ambo (жив.) }\end{array}$ & \\
\hline памбиа (3) & $a k o$ & & $\begin{array}{l}-a k o \text { (лич.), - } a m b a \\
\text { (Жив.) }\end{array}$ & \\
\hline геме (3) & $y \bar{e}$ & & & \\
\hline нзакара (3) & àkó-, àkj̄ & $\begin{array}{l}\text {-àkò (лич.), -a(ra) } \\
\text { (жив.) }\end{array}$ & $-\hat{a} k o$ & $\begin{array}{l}\text { àkó (лич.), à (Жив.), } \\
\text { si / ti (INAN) }\end{array}$ \\
\hline
\end{tabular}

В языках убанги существует общая тенденция образовывать формы 3PL префиксацией к соответствующим формам сингуляриса:

нзакара (группа занде) kó- 'он' - àkó- 'они',

якома (группа нгбанди) lò 'он, она' - álà 'они',

ндунга (группа мба) те́ 'он, она' - làmé 'они’,

ЗЦ-були (группа гбая) 2à 'он, она' - mbúá ‘они', и др.

Исходя из этой закономерности, можно проецировать происхождение формы праязыка банда *ànjē из местоимения 3SG *Cè / *Cà с добавлением некоторого префикса *ànили $\check{\tilde{a}}-$, приведшего к озвончению интервокальной согласной. На это же указывает и одинаковый характер финальной гласной в формах единственного и множественного числа - так, в мбанджа это -a, в мбрес -е и т.д.

Соответственно, для группы гбая плюрализующей морфемой является *mbu-, в большинстве диалектов реализующаяся как “w-. То, что mbúà и wà происходят из единого источника, подтверждается не только их фонетическим сходством, но и тем, что в языках гбая они находятся в дополнительной дистрибуции, то есть никогда не встречаются вместе в одном языке в рамках системы личного маркирования. Гласная демонстрирует низкий тон, характерный для неё и в местоимении единственного числа. Не очень понятно, как в этом случае объяснить огласовку -о в таких языках, как бокото; однако возможно, что она явилась следствием сдвига ряда гласной под влиянием огублённого глайда, т.е. *mbw-à > wò. Весьма вероятно, что форма уа̀ в бофи является палатализованным вариантом той же лексемы.

Языки нгбанди демонстрируют местоимение *álà, о происхождении которого из формы 3SG уже говорилось выше. Из языка якома это же местоимение попало в креольский язык долины реки Убанги - санго. 
В языках нгбака наиболее распространённым является местоимение wó или ó. Имеется ли общность происхождения между этой формой и упоминавшимся чуть выше местоимением гбая *wà, неясно. Стоит, однако, отметить здесь, что в других нигеро-конголезских языках Западной и Южной Африки (семьи бенуэ-конго, ква, гур, атлантические) в качестве местоимения ЗРL лиц наиболее употребительным является именной классный префикс * $b V$ - (например, банту *ba-, ква $b e, b a, b o$, гур $b a, b I, p e)$. Рефлексы этого показателя, восходящего к нигеро-конголезскому уровню, в ряде языков принимают и форму с утерей губной смычки: например, в языках ква: эве wó, акан wо- / wo- / wa-, абуре $v e$; в языках гур: лама $w a$, лоби $w v$ и пр. Другим возможным соответствием в этом ряду является местоимение 3PL $b \varepsilon$ / бе́ в языке мба. Дюбопытно было бы сопоставить с этими формами и местоимения 3SG убангийских языков, что стало бы одним из подтверждений существования в последних реликтов нигеро-конголезской системы именных классов. Однако данный вопрос, пожалуй, требует разбора с учётом и других характеристик именной системы, а потому заслуживает отдельной большой работы.

В языках мба общий предок местоименных форм ЗРL не восстанавливается. Форма ндунга является однокоренной с местоимением 3SG, оба одушевлённых местоимения 3 лица (zé и zѝ) генетически связаны и в донго-ко.

Языки занде для обозначения лиц-референтов показывают местоимение ako / aka, образованное префиксацией от соответствующей формы 3SG. Однако в языке занде оно отсутствует (хотя в наличии форма 3SG ko), что может свидетельствовать о возникновении новообразования. Для праязыка занде можно, таким образом, на основании этой информации реконструировать форму *ako / aka. Её тональная структура уже в праязыке видоизменялась в зависимости от грамматического значения и лексического тона предиката. Для неодушевлённых референтов устанавливается форма праязыка занде-нзакара *si / *ti; данных по другим языкам группы недостаточно.

Что же касается языков сере, то здесь общей праформой по материалам языков сере и баи является *ndi, также либо генетически родственная, либо испытавшая взаимное аналогическое влияние с формой 3SG ní.

Из таблицы 14 видно, что в большинстве групп семьи существует формальная корреляция между местоимениями 3 лица обоих чисел. Это сходство может быть результатом как аналогического выравнивания (например, в сере), так и общего генетического происхождения. Генезис местоимений обоих лиц от единой лексемы - явление, нехарактерное для местоимений двух первых лиц (особенно для первого лица). То, что оно значительно ярче проявляет себя именно в третьем лице, является ещё одним подтверждением особого происхождения форм, обозначающих нелокуторов, и, возможно, происхождения более позднего, нежели форм 1-2 лица.

Таблицьа 14

\begin{tabular}{l|l|l}
\hline & 3SG & 3PL \\
\hline банда & *Cè / *Cà (AN), *a (INAN) & *ànjē \\
\hline гбая & *2à / *2à̀, *wènc̀ (AN) & *wà < *mbú-à ? \\
\hline нгбанди & якома $a$ (INAN) & *álà \\
\hline нгбака & *?é / *2á & *wó \\
\hline сере & *ní & *ndí \\
\hline занде & *kó (M), *né / *ní (F) & *ako / *aka (лич.), *sí (INAN) \\
\hline
\end{tabular}


Проведённый в настоящем исследовании анализ, хотя и является в своём роде первым, включающим обзор данных по большинству языков убангийской семьи, не может претендовать на безусловную корректность. К сожалению, по многим языкам мы не располагаем морфологическими и лексическими данными, позволившими бы нам найти подтверждения для любого фонетического соответствия между местоименными формами. Это задача тем более сложная, что местоимения подчас демонстрируют весьма нетривиальные фонологические процессы, параллели которым можно обнаружить лишь в других системах грамматических морфем, но не среди полнозначных лексем. При отсутствии исчерпывающих данных такое сравнение во многих случаях пока недоступно, а сделанные выводы временами вынуждены нести предварительный, гипотетический характер. В связи с изложенным, в предлагаемой реконструкции мы стремились к максимальной осторожности в постулировании праязыковых форм и строгому соблюдению принципа ступенчатой реконструкции. Мы рисуем первый контур гипотезы и наносим бережную штриховку научного доказательства. Однако можно считать бесспорным, что по мере обретения наукой новых данных о различных языках и диалектах убангийской семьи, а также соседних с ними языках ареала предложенная картина праязыка будет неизбежно уточняться и корректироваться.

Формы личных местоимений праязыка убанги приведены в таблице 15. Для удобства анализа здесь же приведены формы промежуточных праязыков групп.

Таблициа 15

\begin{tabular}{|c|c|c|c|c|c|c|}
\hline & $1 \mathrm{SG}$ & $2 S G$ & $1 \mathrm{PL}$ & $2 \mathrm{PL}$ & $3 S G$ & 3PL \\
\hline банда & mà & 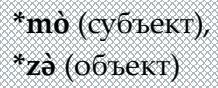 & 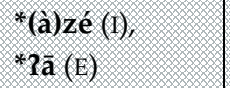 & ne & $\begin{array}{l}{ }^{*} \mathrm{Cè} /{ }^{*} \mathrm{Cà}(\mathrm{AN}), \\
\text { *a (INAN) }\end{array}$ & $\begin{array}{l}\text { *ànjē } \\
<* a ̀ n-C e ̀ ? ~\end{array}$ \\
\hline гбая & mi & me & (?E)] & $(P E) n E$ & *à / *wغ̀nغ̀ (AN) & ${ }^{*} \mathbf{w a ̀}<{ }^{*} m b u ́-\grave{a} ?$ \\
\hline нгбанди & mi & mo & $h e,-n e(\mathrm{I})$ & groma hi < Ni & якома $a$ (INAN) & *álà \\
\hline нгбака & ma & mo 1 mu & ${ }^{*}$ na / *ni & $y_{1}$ & *?é / * Tá & *wó \\
\hline мба & $n V / m u$ & * mol * mu? & ${ }^{*}$ na / *ni? & na / na / da & kó (M) & $b \varepsilon / z \grave{u}(\mathrm{AN})$ \\
\hline cepe & $y \bar{e} / n \bar{e}$ & $w \bar{o} / \eta \bar{o}$ & di & *dā? & *ní & *ndí \\
\hline занде & mi & mo & *à(nì) & * V)ni & $\begin{array}{l}\text { *kó (M), } \\
\text { *né / *ní (F) }\end{array}$ & $\begin{array}{l}\text { *ako / *aka } \\
\text { (лич.), } \\
\text { *sí (INAN) }\end{array}$ \\
\hline убанги & ${ }^{*} \mathrm{mi}$ & ${ }^{*}$ mo & $*(\mathrm{~V}) \mathrm{de} / *(\mathrm{~V}) \mathrm{di}$ & ${ }^{*}(\varepsilon)$ ne $/{ }^{*}(\varepsilon)$ ni & & \\
\hline
\end{tabular}

Данные таблицы 15 позволяют высказать несколько соображений как о надёжности реконструкции отдельных праформ, так и о внутренней генеалогической классификации языков убангийской семьи.

Хорошо видно, что языки групп сере и мба менее других отражают предложенную праязыковую парадигму. В частности, только эти две группы не имеют рефлексов убангийских местоимений 1SG. И мба, и сере демонстрируют лишь по одному соответствию реконструированной системе, что делает их положение в составе семьи убанги, конечно, несколько шатким. Это особенно чётко просматривается в сравнении с такими языками, как банда, гбая, нгбака и занде, которые, хотя и значительным образом разнесены с географической точки зрения, сохранили надёжные парадигматические соответствия между местоимениями. Чрезвычайно близки - вплоть до картины тонов - парадигмы, например, западно-центральных диалектов банда и языка монзомбо (группа нгбака), географически расположенных в различных регионах ЦАР (Таблица 16). 


\begin{tabular}{l|l|l|l|l}
\hline & $1 \mathrm{SG}$ & $2 \mathrm{SG}$ & $1 \mathrm{PL}$ & 2PL \\
\hline ЗЦ & $m \bar{a}$ & $m o ̀$ & $2 \grave{a}(\mathrm{I}), \imath \bar{a}(\mathrm{E})$ & $\imath \bar{e}$ \\
\hline монзомбо & $m \bar{a}$ & $m \tilde{o}$ & $n a ́(\mathrm{I}), \imath \bar{a}(\mathrm{E})$ & $\imath \bar{\imath}$ \\
\hline
\end{tabular}

Языки указанных четырёх групп составляют, согласно получившейся картине, ядро убангийской семьи, в то время как группы сере и мба по своим характерным отличиям можно назвать периферийными. Этой характеристике соответствует и географическое положение данных языков в ареале, занятом носителями языков убанги - на крайнем северо-западе и юго-западе, соответственно. Безусловно, можно было бы предположить, что трансформация местоименной системы происходила в указанных группах языков под сильным влиянием иноязычного окружения (языки банту, центральносуданские). Однако те формы, которые выглядят несопоставимыми с убангийскими, как раз не имеют параллелей в языках, контактирующих с сере и мба. Нет и достаточных оснований считать языки сере и мба выпадающими из состава убангийской семьи: лексические и морфосинтаксические данные, рассмотренные в различных работах (обзор см. [Воуd 1989]), подтверждают значительные сходства между сере и мба, с одной стороны, и другими убангийскими языками, с другой. Этот вывод подкрепляется и рядом местоименных изоглосс, видных из вышеприведённой таблицы: в частности, форма 1PL *dī в сере надёжно соответствует праязыковой реконструкции. Форма типа пi в 1PL мба также может относиться к тому же источнику, а назализация этой формы может рассматриваться как общая изоглосса языков нгбанди (якома инкл. álé-nè), занде (занде à-nì / rà-nì) и нгбака (мунду $n \bar{\imath}$, бака инкл. $n \grave{\imath})$.

Не подлежит сомнению, как видно из работы [Pasch 1986], и общее происхождение различных языков мба, демонстрирующих весьма значительные расхождения в парадигмах местоимений. И тем не менее, данные анализа местоименной системы заставляют более пристально рассмотреть генетические и ареальные связи языков сере и мба.

Для убангийских языков наиболее стабильными членами парадигмы являются формы сингуляриса первых двух лиц. Здесь мы видим минимальное количество расхождений и незначительное число инноваций по отдельным языкам. Что касается форм 1PL, то на пёстрый состав засвидетельствованных морфем повлияло создание категории расширенного множественного числа, произошедшее, как можно видеть, уже после распада праязыка или по крайней мере в его отдельных диалектах - наиболее последовательно в банда. При этом можно видеть, что исходное праязыковое местоимение 1PL в этом случае получало инклюзивное значение; что же касается форм эксклюзива, они нередко создавались как деривативы от соответствующих форм 1SG (как в якома).

Местоимения 3 лица не сводятся в убанги к общему праязыковому источнику. Весьма вероятно, что морфемы, играющие ныне роль личных местоментий в современных языках, в праязыке выполняли иные функции: для некоторых из них (например, в языке мба) можно проследить функциональный параллелизм с показателями именных классов. Образование плюральных местоимений 3 лица демонстрирует тенденцию к агглютинации, а именно к префиксации некоторого плюрального элемента к местоимению 3SG. Такой элемент в тех же языках часто играет роль нормального показателя именной множественности: например, в языках занде в обеих целях используется префикс $a$ (нзакара gbéngé ‘вождь' - PL a-gbéngé; kó ‘он' - àkó ‘они’).

Вопрос о происхождении убангийских местоимений в нигеро-конголезской перспективе заслуживает особого внимания в свете уже упоминавшихся сомнений ряда 
лингвистов в принадлежности языков убанги к макросемье нигер-конго. Местоименные парадигмы представляют довольно убедительные подтверждения генетического родства форм между убангийскими и другими языками макросемьи. Помимо несомненно нигеро-конголезского местоимения 1SG *mi, такие подтверждения можно найти и во всех прочих формах. Как уже было замечено в статье [Williamson \& Blench 2000: 28], местоимение 2SG * то позволяет сравнить убангийские языки с языками сенуфо, а также с рядом периферийных языков семьи гур, адамауа, но не только: ту же форму мы видим и в южноатлантических языках. Местоимение $1 \mathrm{PL} *(V) d e$ / *(V)di вполне соответствует целому ряду праформ, реконструируемых для различных семей языков нигер-конго (как уже упоминалось выше, это гур *tI, бенуэ-конго и ква *tv / *ti), а также формам отдельных языков других семей, в частности, атлантических (биджого). В 2PL также существует

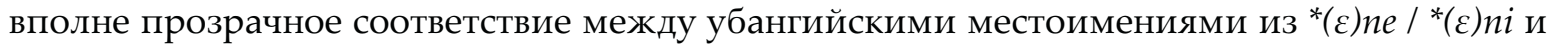
праформами гур, ква, бенуэ-конго. В то же время языки семей, не входящих в состав нигер-конго, с которыми соседствуют убангийские языки, нигде не демонстрируют формально схожих парадигм личных местоимений.

\section{Список сокращений}

$\begin{array}{llll}\text { AN } & \text { одушевлённое } & \text { PF } & \text { перфект } \\ \text { CONJ } & \text { союз } & \text { PL } & \text { множественное число } \\ \text { DO } & \text { прямой объект } & \text { PRES } & \text { настоящее время } \\ \text { DU } & \text { двойственное число } & \text { PROSP } & \text { проспектив } \\ \text { E } & \text { эксклюзив } & \text { QUOT } & \text { квотативный маркер } \\ \text { F } & \text { женский род } & \text { S } & \text { субъект } \\ \text { FUT } & \text { будущее время } & \text { SG } & \text { единственное число } \\ \text { GEN } & \text { генитив } & \text { SUBJ } & \text { сослагательное наклонение } \\ \text { I } & \text { инклюзив } & \text { TOP } & \text { топикализованное } \\ \text { IMP } & \text { повелительное наклонение } & \text { гл. } & \text { глагольный показатель } \\ \text { INAN } & \text { неодушевлённое } & \text { жив. } & \text { животные } \\ \text { IO } & \text { непрямой объект } & \text { лич. } & \text { личное } \\ \text { IPF } & \text { имперфект } & \text { негл. } & \text { неглагольный показатель } \\ \text { LOG } & \text { логофорическое } & \text { притяжат. притяжательное } \\ \text { M } & \text { мужской род } & \text { фокал. } & \text { фокализованное } \\ \text { O } & \text { объект } & & \end{array}$

\section{Питература}

Baumann H., Thumwald R. \& Westermann D. 1940. Völkerkunde von Afrika. Essen.

BennetT, Patrick R. 1983. Adamawa-Eastern: Problems and prospects // DiHoff, Ivan R. (ed.). Current Approaches to African Linguistics. Vol 1. Dordrecht: Foris. Pp. 23-48.

BHAt, D. N. S. 2005. Pronouns. Oxford: Oxford University Press.

Boyd, R. \& P. NOugayrol. 1988. Le gèmé ou jèmé, une nouvelle langue du groupe zande // MoÑinO, Y. (ed.). Lexique comparatif des langues oubanguiennes. Paris: Geuthner.

BOYD, Raymond. 1988. Le kpatiri ou gbayi, une nouvelle langue du groupe ngbandi // MoÑINO, Y. (ed.), Lexique comparatif des langues oubanguiennes. Paris: Librairie Orientaliste Paul Geuthner pour la Laboratoire de Langues et Civilisations à Tradition Orale (LACITO) / Département Languages et Parole en Afrique Central (LAPAC). Pp. 35-49.

BoyD, Raymond. 1989. Adamawa-Ubangi // BENDOR-SAMuEL, John (ed.) Niger-Congo Languages. NY - London: Lanham, 1989. Pp. 178-215. 
BOYD, Virginia Lee. 1997. A phonology and grammar of Mbódj̀m̀̀. Ph.D. Thesis. Arlington: University of Texas.

Boyeldieu, Pascal. 1987. Les langues fer («kara») et yulu du nord Centrafricain. Esquisses descriptives et lexiques. Paris: Geuthner.

BOYELDIEU, Pascal. 1995. Le yakoma // BOYD, R. (ed.), Le système verbal dans les langues oubangiennes, München.

BRISSON, R. \& D. BOURSIER. 1979. Petit dictionnaire baka-français. Douala: Collège Libermann V, XXII.

ClAUdI, U. 1985. Zur Entsichung von Genussystemen, Überlegungen zu einigen theoretischen Aspekten, verbunden mit einer Fallstudie des Zande. Hamburg: Buske.

CysOuW, Michael. 2003. The Paradygmatic Structure of Person Marking. Oxford: Oxford University Press.

Delafosse, Maurice. 1924. Langues du Soudan et de la Guinée // Meillet A., CoHeN M. (eds.). Les langues du monde. Paris: Champion.

DimmendAAL, Gerrit. 2008. Language Ecology and Linguistic Diversity on the African Continent // Language and Linguistics Compass, 2/5: 841.

GreEnberG, Joseph. 1963. The Languages of Africa. The Hague: Mouton; IJAL 29.1, Bloomington: Indiana University Press.

Helmbrecht, J. 2004. Personal Pronouns - Form, Function and Grammaticalization. Erfurt.

LEWIS, M.P. (ed.). 2009. Ethnologue: Languages of the World, 16 $6^{\text {th }}$ edition. Dallas: SIL International, 2009. [http://www.ethnologue.com].

MOÑINO, Yves (ed.). 1988. Lexique comparatif des langues oubanguiennes. Paris: LACITO / LAPAC.

MoÑINO, Yves. 1980. Dialectologie et parenté génétique des langues. Applications méthodologiques à un groupe homogène de langues // GuARIsma, G. \& S. Platiel (eds.). Dialectologie et comparatisme en Afrique noire. Paris: SELAF. Pp. 61-77.

MOÑINO, Yves. 1981. De 2 à 3 tons, l'évolution tonale dans les langues gbaya-manza-ngbaka // GuARISMA, G. (ed.). Tons et accents dans les langues africaines. Paris: SELAF. Pp. 65-101.

MoÑINO, Yves. 1995. Le Proto-Gbaya: Essai de linguistique comparative historique sur vingt-et-une langues d'Afrique centrale. Louvain-Paris: Peeters.

Mortier, R. 1941. Classificate der talen van Ubangi // Aequatoria, vol. 4, p. 1-8.

MORTIER, R. 1946. Ubangi onder linguistisch opzicht // Aequatoria, vol. 9, p. 104-112.

Moser, R. 2004. Kabba: a Nilo-Saharan language of the Central African Republic. München: LINCOM Europa.

Noss, P. 1969. The Gbaya predicate. Madison: University of Wisconsin.

Nougayrol, P. 1999. Les parlers gula: Centrafrique, Soudan, Tchad. Grammaire et lexique. Paris: CNRS.

OlsON, Kenneth. 1996. On the comparison and classification of Banda dialects // Chicago Linguistic Society (CLS), 32(1). Pp. 267-283.

Olson, Kenneth. 2001. The phonology and morphology of Mono. Vol. 1. Ph.D. Thesis. Chicago: University of Chicago.

PASCH, Helma. 1986. Die Mba Sprachen. Die Nominalklassensysteme und die genetische Klassifikation einer Gruppe von Ubangi-Sprachen. PhD Theses. Beihefte zu SUGIA 6. Hamburg: Helmut Buske.

POZDNIAKOV, Konstantin \& GuILlaume Segerer. 2004. Reconstruction des pronoms atlantiques et typologie des systèmes pronominaux // Ibriszimow, D. \& SEGERER, G. (eds.). Systèmes de marques personnelles en Afrique. Collection «Afrique et Langage», 8, p. 151-162. Louvain - Paris: Peeters.

RICHARDSON, Irvine. 1957. Linguistic Survey of the Northern Bantu Borderland, Vol 2. London: Oxford University Press for the International African Institute.

ROULON-DOKO, Paulette. 1993. Les personnels et les modalités de vouvoiement en gbaya 'bodoe (Centrafrique) // Linguistique africaine 11 , pp. 67-82.

SAMARIN, W. 1966. The Gbeya language: grammar, texts and vocabularies. Berkeley - Los Angeles: University of California.

SAMARIN, W. 1971. Adamawa-Eastern // T. SEBEOK (ed.). Linguistics in Sub-Saharan Africa. Current Trends in Linguistics, vol. 7. The Hague - Paris, 1971. Pp. 213-244.

SAMPSON, Douglas. 1997. The pronouns of Banda-Tangbago of Sudan // Occasional papers in the study of Sudanese languages 7, pp. 91-102.

SANTANDREA, Stefano. 1950. Indri - Togoyo - Ndogo - Feroge - Mangaya - Mondu: Comparative Linguistics. Verona: Missioni Africane.

SAXON, Douglas. 1982. Linguistic evidence for the eastward spread of Ubangian peoples. // EHRET, C. \& M. POSNANSKY (eds.). The Archaeological and linguistic reconstruction of African history. Berkeley: University of California. Pp.66-77. 
SEGERER, Guillaume. 2002-2007. Les marques personnelles dans les langues africaines, [base de données en ligne]. http://sumale.vjf.cnrs.fr/pronoms

TISSERANT, Charles. 1930. Essai sur la grammaire Banda. Paris: Institut d'ethnologie.

Tucker, A. N. \& Bryan, M. A. 1956. The Non-Bantu languages of North-Eastern Africa. Oxford: Oxford University Press.

TUCKER, A. N. 1959. Le groupe linguistique zandé. Tervuren: Musée Royal du Congo belge.

VALlAeYs, André. 1991. La langue mondo: esquisse grammaticale, textes et dictionnaire. Tervuren: Musée Royal de l'Afrique Centrale.

WESTERMANN, D. 1911. Die Sudansprachen, eine sprachvergleichende Studie. Hamburg.

WestermanN, Diedrich \& Margaret BryAn. 1952. The Languages of West Africa. Handbook of African Languages 2. London: Oxford University Press.

Williamson, Kay \& Roger Blench. 2000. Niger-Congo // Heine, Bernd and Nurse, Derek (eds.). African Languages - An Introduction. Cambridge: Cambridge University Press, pp. 11-42.

БАБАЕВ К. В. О происхождении личных местоимений в языках мира // Вопросы языкознания, 4, 2009. С. 119138. [BABAEV K. V. O proiskhozhdenii lichnykh mestoimenij v yazykakh mira // Voprosy yazykoznaniya, 4, 2009. S. 119-138.]

The present paper continues a series of publications devoted to the comparative analysis of person marking systems in Niger-Congo languages. The article examines person markers of the Ubangi languages of Central Africa and proposes a reconstruction of the pronominal paradigm for the proto-language.

Keywords: person marking, personal pronouns, Ubangian languages, Niger-Congo languages, African languages. 